\title{
COMPARATIVE REgIONALISM
}

A New Research Agenda

Tanja A. Börzel

No. 28 | August 2011 


\section{KFG Working Paper Series}

\section{Edited by the Kolleg-Forschergruppe "The Transformative Power of Europe"}

The KFG Working Paper Series serves to disseminate the research results of the Kolleg-Forschergruppe by making them available to a broader public. It means to enhance academic exchange as well as to strengthen and broaden existing basic research on internal and external diffusion processes in Europe and the European Union.

All KFG Working Papers are available on the KFG website at www.transformeurope.eu or can be ordered in print via email to transform-europe@fu-berlin.de.

Copyright for this issue: Tanja A. Börzel

Editorial assistance and production: Farina Ahäuser and Corinna Blutguth

Börzel, Tanja A. 2011: Comparative Regionalism: A New Research Agenda, KFG Working Paper Series, No. 28, August 2011, Kolleg-Forschergruppe (KFG) "The Transformative Power of Europe“, Freie Universität Berlin.

ISSN 1868-6834 (Print)

ISSN 1868-7601 (Internet)

This publication has been funded by the German Research Foundation (DFG).

Freie Universität Berlin

Kolleg-Forschergruppe

"The Transformative Power of Europe:

The European Union and the Diffusion of Ideas"

Ihnestr. 26

14195 Berlin

Germany

Phone: +49 (0)30- 83857033

Fax: +49 (0)30- 83857096

transform-europe@fu-berlin.de

www.transformeurope.eu

Deutsche

Forschungsgemeinschaft DFG 


\title{
COMPARATIVE REgIONALISM
}

\author{
A New Research Agenda
}

\author{
Tanja A. Börzel
}

\begin{abstract}
After the end of the Cold War, students of International Relations observed an expansion of inter-state activities at the regional level. Regional and sub-regional groupings appeared to gain momentum as the way in which countries cooperate and should cooperate to pursue peace, stability, wealth and social justice. The surge and resurgence of regionalism has triggered the proliferation of concepts and approaches. The focus of this paper will be on processes and structures of state-led regionalism driven by the delegation of policies and political authority to regional institutions. Based on this understanding of regionalism, the existing literature will be reviewed with regard to three general questions. These questions do not only require research across regions but also allow developing a common research agenda to accumulate knowledge generated about specific regions. First, what are the outcomes of regionalism? How can we describe and compare the results of the delegation of policies and political authority? Second, what are the drivers of regionalism? Why do some governments choose to delegate policies and political authority while others do not? Finally, what are the internal effects of regionalism? How does the delegation of policies and political authority impact back on the domestic structures of the states involved?
\end{abstract}

\section{The Author}

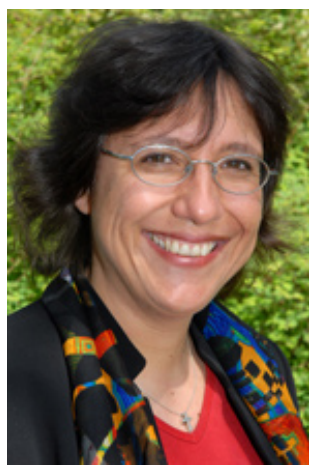

Tanja A. Börzel is Professor of Political Science and holds the chair for European Integration at the Otto Suhr Institute of Political Science, Freie Universität Berlin. Her research concentrates on questions of Governance, institutional change as a result of Europeanization as well as on the diffusion of ideas and policies within and outside of the European Union. Since October 2008, she coordinates the Research College "The Transformative Power of Europe" together with Thomas Risse.

Contact: europe@zedat.fu-berlin.de 


\section{Contents}

1. Introduction

2. The History of Regionalism: European Integration and Beyond

3. The Outcome of Regionalism: Inter-, Supra- or Post-National? 8

3.1 From Cooperation to Integration 8

3.2 New and Old Regionalism 10

3.3 Persisting Diversity or Emerging Similarity? 13

4. The Drivers of Regionalism: Old Theories and New Puzzles 16

4.1 The Demand for Regionalism. It Is Not Only the Economy, Stupid! 16

4.2 The Supply of Regionalism. Interests, Power, and Norms 20

5. When Regionalism Hits Home. Policy Harmonization and Structural Change 22

5.1 From Second Image Reversed... $\quad 22$

5.2 ... to Europeanization and Domestic Change 23

$\begin{array}{lr}\text { 6. Conclusions } & 26\end{array}$

$\begin{array}{lr}\text { Literature } & 28\end{array}$ 


\section{Introduction ${ }^{1}$}

After the end of the Cold War, students of International Relations (IR) observed an expansion of inter-state activities at the regional level. Regional and sub-regional groupings appeared to gain momentum as the way in which countries cooperate and should cooperate to pursue peace, stability, wealth and social justice. The surge and resurgence of regionalism has triggered the proliferation of concepts and approaches. There is new and old regionalism, regionalism in its first, second and third generation; economic, monetary, security and cultural regionalism, state regionalism, shadow regionalism; cross-, inter-, trans-, and multiregionalism; pure and hybrid regionalism; offensive, extroverted, open, or neoliberal as opposed to defensive, introverted, closed, resistance, regulatory and developmental regionalism; lower level and higher level regionalism; North, South, and North-South regionalism; informal and institutional regionalism - just to name a few of the labels the literature has come up with to account for the new trend in International Relations.

The concept of regionalism is as diverse as its object of study. There is no commonly accepted definition of what a region is (cf. Sbragia 2008). Most would agree that a region implies some "geographical proximity and contiguity" (Hurrell 1995: 353), and mutual interdependence (Nye 1965: vii). Some would add a certain degree of cultural homogeneity (Russett 1967), sense of community (Deutsch et al. 1957), or "regioness" (Hettne/Söderbaum 2000). Regionalism, then, refers to processes and structures of regionbuilding in terms of closer economic, political, security and socio-cultural linkages between states and societies that geographically proximate. In political science, regionalism is often used synonymous with regional cooperation and regional integration, which could be seen as the opposite ends of a continuum along which regionalism may vary.

It is beyond the scope of this paper to do justice to the various bodies of literature that have emerged in the field of (comparative) regionalism. The focus will be on processes and structures of state-led regionalism driven by the delegation of policies and political authority to regional institutions. Based on this more narrow understanding of regionalism, the existing literature will be reviewed with regard to three general questions. These questions do not only require research across regions but also allow developing a common research agenda to accumulate knowledge generated about specific regions. First, what are the outcomes of regionalism? How can we describe and compare the results of the delegation of policies and political authority? Second, what are the drivers of regionalism? Why do some governments choose to delegate policies and political authority while others do not? Finally, what are the internal effects of regionalism? How does the delegation of policies and political authority impact back on the domestic structures of the states involved? Before reviewing the state of the art on these three questions, the chapter will trace the history of the study of regionalism in IR.

1 This paper benefitted from comments and suggestions by Eugenia Conceicao-Heldt, Liesbet Hooghe, Vera van Hüllen, Jolyon Howorth, Anja Jetschke, Tobias Lenz, David Levi-Four, Ulrike Lorenz, Gary Marks, Thomas Risse, Osvaldo Saldías, Vivien Schmidt, Beth Simmons, and the participants of the KFG Research Colloquium "Transformative Power of Europe". 


\section{The History of Regionalism: European Integration and Beyond}

The study of regionalism has a long history and evolved in several waves giving rise to quite diverse bodies of literature. The creation of the United Nations spurred a debate on whether regional organizations would be better suited than universal organization to settle disputes and conflicts among geographically proximate states (Haas 1956; Wilcox 2965). While the universalist-regionalist debate was about security issues, the emergence of European integration in the 1950s shifted attention towards economic regionalism, particularly when attempts to establish a European Defence Community had failed in 1953. After European states had fought two major wars of global scale in less than 50 years, regionalism became the strategy for securing peace and reconciliation in Europe. The delegation of national sovereignty rights to a regional authority should tame nationalism and foster the peaceful resolution of international conflict. The key question was how to overcome the reluctance of states to give up sovereignty. The so-called federalist approaches advocated a radical solution by which a constitutional convention of the peoples of Europe would create a United States of Europe. Students of International Relations were less optimistic that nation states would simply transfer their sovereignty to a newly created European (federal) state (Spinelli/Rossi 2006 (1941)). Functionalism therefore recommended starting cooperation in limited functional, technical, and/or economic areas of "low politics" where sovereignty losses would be limited while the pooling of technical expertise in administrative networks would yield tangible benefits by solving common problems. The experience of mutually beneficial cooperation and the functional linkage between issue areas was to create further incentives for the gradual expansion of tasks (Mitrany 1943).

Such spill-over effects also formed the core of neo-functionalism as coined by Ernst Haas. Yet, he emphasized the importance of politics since regional integration always produced winners and losers (Haas 1958, 1964; Lindberg 1963; Lindberg/Scheingold 1971). Moreover, neo-functionalism focused on the role of transnationally organized pressure groups rather than technocratic and administrative networks as the main actors behind functional task expansion to the regional level. Business interests were better served by market integration at the regional level and therefore they would push for the delegation of policies and political authority to regional institutions. With policies increasingly made at the regional rather than the national level, economic and societal actors would increasingly shift their expectations and loyalties towards regional institutions giving rise to a new political community, in which states would settle their conflicts peacefully.

Community-building was also at the core of transactionalist approaches as developed by Karl Deutsch (Deutsch et al. 1957). His "security community" was formed by a group of states, which no longer considered force as a means to solve conflict. They remain formerly independent in pluralistic security communities. If states engaged in peaceful change agreed to politically merge they became amalgamated security community. While regional institutions helped solve conflicts, cross-border social and economic transactions and communication were seen as the main drivers of community-building. Both, neofunctionalism and transactionalism considered transnational interests as the main actors in overcoming the resistance of states against regionalism. Intergovernmentalism, by contrast, followed realist reasoning and insisted that states remained resilient to shifting policies and political authority to regional institutions, particularly in areas of "high politics" (Hoffmann 1966). 
The founding of the European Economic Community (EEC) in 1957 and its rapid deepening into a customs union had vindicated neofunctionalist thinking. It had also touched off a wave of regionalism in other parts of the world, particularly in Latin America and to a lesser extent in Africa (Malamud 2010; Fawcett/Gandois 2010), and induced some first attempts at comparative regionalism by testing neofunctionalist explanations beyond Europe (Haas/Schmitter 1964; Haas 1967; Nye 1965). Yet, plans for a European Economic and Monetary Union failed and the integration process seemed to stall in the 1970s. Likewise, efforts at "South-South" integration largely remained ineffective. The absence of certain context conditions, such as high level of economic and political pluralism, could account for why regionalism in other parts of the world proved far less successful (Haas 1970). Neofunctionalism could not explain, however, why European states abandoned collective problem-solving in times of crisis. With regionalism not making progress in Europe and other parts of the world, Haas declared regional integration theory altogether obsolete (Haas 1975).

The Single European Act of 1986 and the Maastricht Treaty of 1990 ended the times of "eurosclerosis". Together with the end of the Cold War, the broadening and deepening of the European Community into a European Union did not only trigger another wave of regionalism outside Europe with the US departing from its exclusively multilateral approach to global free trade and states in Africa and Latin America revitalizing existing regional organizations (Fawcett/Gandois 2010; Malamud 2010). It also led to a revival of theorizing about European integration and a reformulation of both neofunctionalist and intergovernmentalist approaches. Supranational institutionalism explained the leap of 1986 and 1990 as a spill-over from market integration to market regulation and emphasized not only the role of the European Commission (Sandholtz/Zysman 1989) but also of the European Court of Justice whose dynamic interpretation of the Treaty of Rome had facilitated the gradual expansion of tasks as early as in the 1960s and 1970s, when European integration had allegedly been in the doldrums (Burley/Mattli 1993; Stone Sweet/Sandholtz 1998a). Liberal intergovernmentalists contended that national governments remained the masters of the treaties and explained the delegation of policies and political authority to supranational institutions as a way to improve collective problem-solving at the regional level. They concurred with neofunctionalist and supranationalist approaches on the importance of domestic (economic) interests but insisted that their demand for more integration was channeled through national governments rather than transnational alliances with supranational actors, who could not simply circumvent national governments as the gate keepers of EU decision-making (Moravcsik 1998). The European Commission and the European Court of Justice were conceived as agents acting at the behest of the member states to advance collective problem-solving at the regional level (Pollack 1997).

The debate between supranational and liberal intergovernmentalist theories shifted the focus of European integration studies from process towards outcome. Multi-level governance approaches emphasized the sharing of political authority in the EU among a mix of state and non-state actors at different levels of government (Hooghe/Marks 2001). The "governance turn" (Kohler-Koch/Rittberger 2006) ended the dominance of IR theories and opened the field of EU studies for comparative politics and public policy analysis (Hix 1994; Wallace/Wallace 1996). Studying the EU as a polity with its own politics and policy-making also paved the way for social constructivism, which engaged in a debate with rationalist and historical institutionalist approaches (Pierson 1996; Aspinwall/Schneider 2000) about how institutions mattered in European integration emphasizing the importance of processes of socialization as well as collective identities and public discourse (Checkel 1999; Risse 2003; Diez 1999). 
After the end of the Cold War, the EU grew from 12 to 27 member states, which required institutional reforms that eventually resulted in the drafting of a Constitutional Treaty by a European Convention in 2003. Its rejection by two referenda in France and the Netherlands, respectively, as well as the adoption of most of the reforms in form of yet another intergovernmental treaty in Lisbon 2009, are likely to trigger new theoretical developments in (European) integration studies since neither supranationalist nor liberal intergovernmentalist approaches can fully account for the stop-and-go in the European integration process (Hooghe/Marks 2009).

EU studies have developed into a sub-discipline of $I R$, with distinctive concepts and theories. At the same time, regionalism gained prominence outside Europe where the end of the Cold War and the Asian financial crisis seemed to have fueled attempts at regional integration. Particularly students in area studies felt that both the IR and the EU literature had little to offer that could help them understand processes of regionalism in Africa or Asia. The so-called "New Regionalism" literature has therefore taken a different approach that emphasizes the social construction of regions, the role of non-state actors other than pressure groups as well as the importance of cultural and environmental aspects (Hettne et al. 1999; Söderbaum/Shaw 2003; Farrell et al. 2005). Finally, International Political Economy (IPE) gave rise to another important body of research on regionalism focusing on regional trade and investment patterns and the design of regional institutions to foster liberalization and settle disputes over market access. The main dependent variable is the emergence and effectiveness of preferential and free trade areas (PTA and FTA), whose number is sufficiently large to apply statistical methods to test varies strands of (rational) institutionalist theories (inter alia Milner 1988; Mansfield/Milner 1997; Mansfield/Reinhardt 2003).

In sum, comparative regionalism as a field of study has been informed by various bodies of research that focus on different aspects and hardly engage with each other. The remainder of this chapter therefore seeks to cut across the different sub-disciplines of IR when taking stock of our empirical and theoretical knowledge of regionalism.

\section{The Outcome of Regionalism: Inter-, Supra- or Post-National?}

\subsection{From Cooperation to Integration}

International Relations treats regionalism as an instance of international cooperation (Haas 1970; Hoffmann 1966; Puchala 1972). Much of the early research concentrated on the European Community/European Union as a long-standing pathfinder in economic and political regionalism. Yet, by 1951 the European Community of Coal and Steel was already more than an international organization. The analytical tool box of IR scholars has always had its limits in capturing the nature of the EU (Puchala 1972). Ultimately, students of the EU declared it unique and described its sui generis nature by new concepts such as a "new, post-Hobbsian order" (Schmitter 1991), “a post-modern state” (Ruggie 1993; Caporaso 1996), "a network of pooling and sharing sovereignty"(Keohane/ and Hoffmann 1991), a "system of multi-level governance" (Hooghe and /Marks 2001) or "network governance" (Eising/ Kohler-Koch 1999). Making the EU a singular case, however, precludes by definition any comparison with other regional institutions. 
The IPE literature managed to avoid such conceptual problems in the first place by looking at economic rather than political regionalism. Existing typologies of economic integration focus on the issue areas covered by regional agreements (trade and/or money) and the degree of interference with national authority on economic affairs (shallow vs. deep, cf. Balassa 1973). The shallowest and most frequent form of trade integration is a preferential trade area (PTA) between two or more countries, which reduces (rather than eliminates) tariffs for certain products. A free trade area (FTA) is a PTA in which all barriers to trade are eliminated. Customs unions are FTA with a common external tariff, which involves the delegation of some trade authority to regional institutions. Common and single markets go even one step further by providing not only for the free movement of goods but also of services, capital and labor. The final stage of trade integration is the economic union, which combines the single market with a monetary union. The depth of monetary integration can equally vary. While the pegging of a state's currency to that of another state is a unilateral and informal commitment, currency boards maintain a fixed exchange rate with a foreign currency, e.g. the US Dollar or the Euro. The deepest form of monetary integration is a currency or monetary union, in which several states share the same currency and establish a supranational central bank to set interest rates. If states use a foreign currency, this is referred to as dollarization (cf. Hancock 2009: 23-25).

The typology of economic integration may be comprehensive. But it blurs two dimensions that ought to be kept separate because they may be causally related. The first dimension, which has been referred to as the scope or breadth of (policy) integration (Lindberg 1970; Lindberg/Scheingold 1970), relates to the issues to be dealt with at the regional level (what sector, how much of it, and how important). These issues do not only concern the dismantling of national barriers to economic exchange (market-making) and the dealing with negative externalities of liberalization (market-correcting; cf. Scharpf 1996). Next to trade and money (economic regionalism), security (security regionalism), constitutional issues referring to institutional norms, rules and procedures (political regionalism) and socio-cultural policy including sustainable development, health, social security and culture (socio-cultural regionalism) can become subject of regionalism. The more policy areas are dealt with at the regional level, the broader integration becomes.

The second dimension, sometimes called level or depth of integration (Lindberg 1970; Lindberg/Scheingold 1970), concerns the political authority regional institutions have over the issue delegated to them. ${ }^{2}$ The delegation or centralization of policy tasks and political authority has provided the starting point for most of the literature that seeks to develop a comparative analytical framework for the outcomes of regionalism (Stone Sweet/Sandholtz 1998b; Hooghe/Marks 2001; Koremenos et al. 2004; Cooley/Spruyt 2009). The weakest form of delegation involves administrative tasks, such as the preparation of intergovernmental meetings or the compilation of information (administration). Substantial delegation, in turn, gives regional institutions the power to adopt collectively binding decisions (legislative authority) and to implement them (executive authority), as well as the autonomy to settle disputes (adjudicative authority). Depending on how much autonomy the regional agents have in exercising their authority and how much they can encroach on national sovereignty rights, regional institutions are intergovernmentalist (minimal autonomy) or supranationalist (maximum authority). Unlike in intergovernmentalist institutions, where states compromise their sovereignty at best by allowing for majority decisions and only delegate certain policy

2 Kathleen Hancock shows in her comparative study on "plutocratic" regional organizations that states can also delegate authority to the wealthiest member state (Hancock 2009). 
functions to administrative or expert committees, states transfer political authority to supranationalist institutions enabling them to take and enforce collectively binding decisions against their will (Scharpf 2001; Börzel 2010a).

Regionalism can be placed on a continuum with regional (intergovernmental) cooperation and regional (supranational) integration as two opposite ends. Regional cooperation entails the joint exercise of statebased political authority in intergovernmental institutions to solve collective action problems related to economic, political or security issues. Regional integration, by contrast, involves the setting-up of supranational institutions to which political authority is delegated to make collectively binding decisions, e.g. on dismantling national barriers to economic and social exchange (market-making), on dealing with negative externalities of liberalization (market-correcting; cf. Scharpf 1996) or on peacefully settling international conflicts (Adler/Barnett 1998).

\subsection{New and Old Regionalism}

The distinction between different outcomes offers some interesting insights regarding the quantity and quality of regionalism. It puts the widely shared observation that regionalism has surged after the end of the Cold War into context. ${ }^{3}$ Claims about the "new urge to merge" (Schulz et al. 2001: 1) are often based on the "explosion" of regional agreements registered with the World Trade Organization (cf. Choi/Caporaso 2002; Hancock 2009: 17-25). By June 2011, the number of regional accords had increased more than five times compared to 1990. Yet, a closer look at the data reveals that the changes are less spectacular than the sheer increase in numbers may suggest. First, of the 489 regional accords registered with the WTO only 297 are in force. Second, a considerable number of the regional trade agreements (about 40 per cent) do not have more than two members, which are in the majority of cases not contiguous either. ${ }^{4}$ About 50 per cent are bilateral and/or include partners from distant regions. Third, the depth of (regional) integration is in the most cases rather shallow. 90 per cent of the regional accords refer to preferential or free trade areas (PTA and FTA). ${ }^{5}$ There are only nine customs unions (four of which involve the EU), six common markets, and four economic unions. ${ }^{6}$ The number of regional organizations has not surged either. ${ }^{7}$ While they may have

3 Inter alia Mansfield/Milner 1999; Mattli 1999b; Fawcett/Hurrell 2000; Breslin 2002; Buzan/Weaver 2003; Katzenstein 2005; Acharya/Johnston 2007.

4 The WTO defines regional trade agreements as "agreements concluded between countries not necessarily belonging to the same geographical region" (http://www.wto.org/english/tratop_e/region_e/scope_rta_e.htm, last access 17 July 2011). RTAs are forms of preferential trade liberalization which by definition cannot be global (cf. Art. 24; http://www.wto.org/english/tratop_e/region_e/regatt_e.htm\#gatt; last access 17 July 2011).

5 The numbers are drawn from the WTO database on regional trade agreements (RTA), which includes only 202 RTA in force (http://www.wto.org/english/tratop_e/region_e/region_e.htm; last access 17 July 2011).

6 Note that each economic and monetary union is a common market and a custom union, and each common market is a custom union. We count every regional organization only once at its deepest stage of economic integration. The numbers are drawn from the WTO Regional Trade Agreements Information System (RTA-IS); http:// rtais.wto.org/UI/publicPreDefRepByRTAType.aspx; and the McGill University PTA Database http://ptas.mcgill.ca/ index.php; last access 17 July 2011.

7 There is no authoritative definition of regional organizations. Unlike international organizations, their geographic 
gained in importance, prominent regional organizations, including the League of Arab States (1945), the Organization of American States (1948), the North Atlantic Treaty Organization (1949), the Council of Europe (1949), the European Union (1957), the European Free Trade Area (1960), the Association of South East Asian Nations (1967), the Caribbean Community and Common Market (1973), the Economic Community of West African States (1975), the Organization (formerly Conference) of Security and Cooperation in Europe (1975), the Gulf Cooperation Council (1981) or the South Asian Association for Regional Cooperation (1985), originated well before the end of the Cold War. Others, such as the South African Development Community (1992), the Andean Community (1996) and the African Union (2002), were reestablishments. Of the more than 50 "multiple issues" regional organizations that exist to date, only 16 were founded after 1990. A third of them are located in the post-Soviet region, which has received little attention in the literature so far (but see Hancock 2009; Collins 2009; Wirminghaus 2012). Undoubtedly, regionalism has increased over time. But the Cold War is not necessarily a watershed (see Table 1). We have seen waves of regionalism before, e.g. in the 1950s and 1960s, particularly in Latin America (Fawcett/Serrano 2005).

Table 1: The Emergence of Regional Organisations since 1945

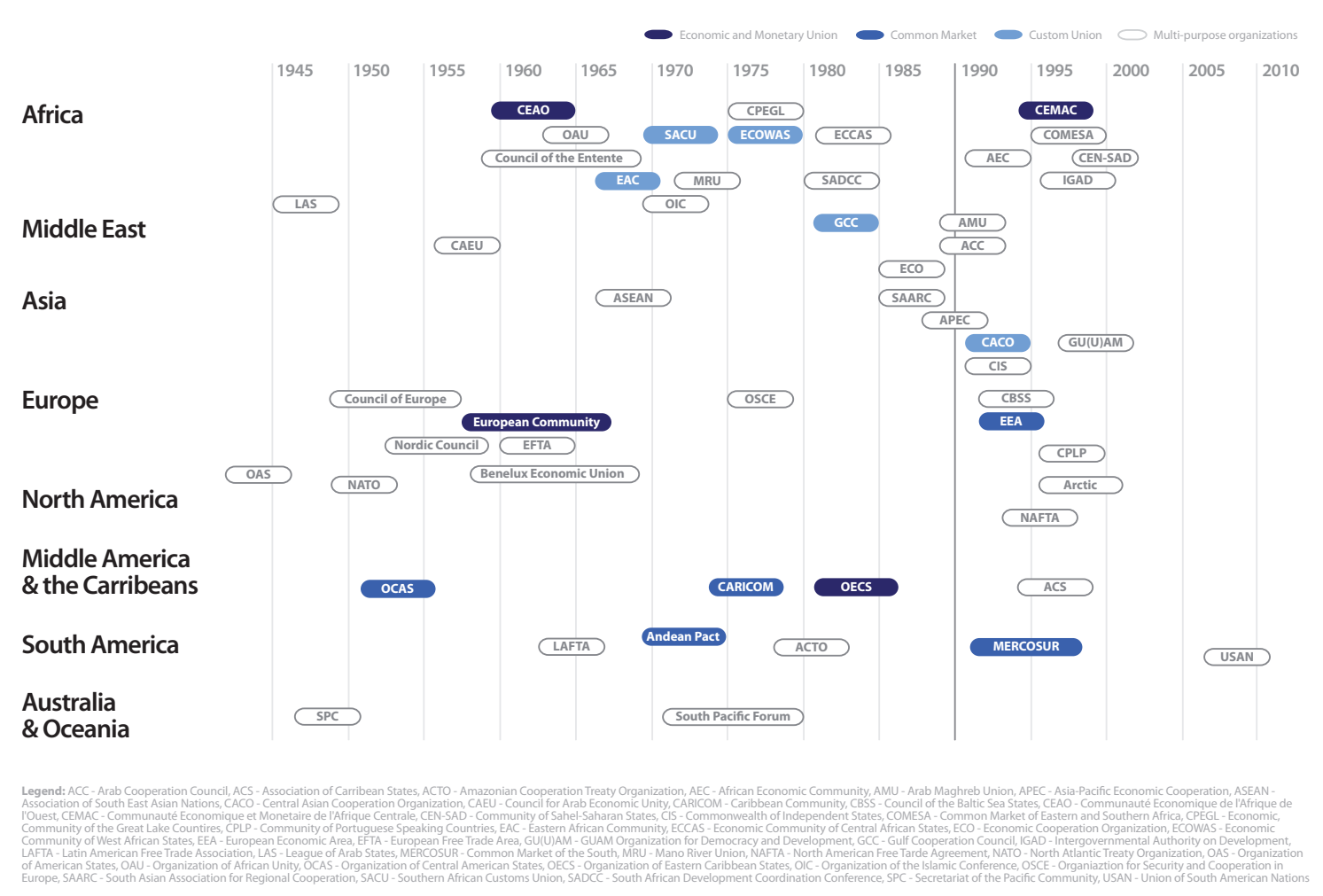

basis precludes global membership (Nye 1971: 8). While the Handbook of International Organizations lists about 100 regional organizations, only half of them cover a broader spectrum of functions and tasks that touch upon more than one issue area (Union of International Associations 2000). 
Analyzing the delegation of policies and political authority to regional institutions also takes issue with claims on the emergence of a qualitatively "new regionalism". First, whether the (quantitative) increase in PTA and FTA indicates a (qualitative) shift away from "introverted, defensive regional blocs" towards innovative and open forms of regionalism that is more compatible with the global trade regime remains an open question (Milner 1992; Bhagwati 2008). While these forms of shallow economic regionalism have been spreading, we also see a deepening and widening of existing forms that started in some cases well before the 1990s. Long-standing regional organizations, such as the League of Arab States (LAS), the European Union, the Association of Southeast Asian Nations (ASEAN) or the Economic Community of West African States (ECOWAS), have experienced the delegation of more authority and new policy competencies as well as the admission of new members. With the creation of the Asian Free Trade Area, ASEAN established for the first time a dispute settlement procedure breaking with the ASEAN way of informal and consensusbased institutions (Kanthak 2012; Korte 2012). The ASEAN Charter provides another major step towards both more political and more legalized integration (Krome 2012; Goltermann 2012). The League of Arab States, which has shared the reluctance of ASEAN to delegate political authority to regional institutions, has become more forthcoming and is planning institutional changes that bear some striking similarities with some changes the Economic Community of West African States introduced (Koitsch 2012). Similar to MERCOSUR (Pirzer 2012) and ASEAN (Krome 2012), ECOWAS committed its members to democracy and seems to have outpaced the EU with its power to use military coercion in order to safeguard democracy (Striebinger 2012).

Second, it is unclear to what extent such quantitative and qualitative changes constitute a new phenomenon that calls for a new approach. Proponents of the "new regionalism approach" have claimed that mainstream theories are "neither designed for nor capable of capturing the multidimensionality, pluralism and comprehensiveness of contemporary regionalization processes, nor the way in which they are socially constructed" (Schulz et al. 2001: 2; Hettne/Söderbaum 2000). IR research might be biased towards statedriven forms of regionalism neglecting more spontaneous and endogenous processes, which involve a variety of non-state actors organized in formal and informal networks. How relevant these "new" forms of regionalism are and to what extent existing theories are adequate to capture them is first of all an empirical question (cf. Hettne 2005: 543; Hettne/Söderbaum 2008; for a suggestion on how to overcome the "false divide" see Warleigh-Lack 2006). We find state-led regionalism in all parts of the world, including those that have been neglected by both the "old" and "new" regionalism literature. The area of the former Soviet Union alone features more than three dozens of regional initiatives based on intergovernmental negotiations and treaties (Wirminghaus 2012). The "alphabet soup" of post-Soviet regionalism shows great similarities with the "spaghetti bowl" regionalism in Africa.

Finally, there is not only a trend towards the delegation of new policy competencies and more political authority within major regional organizations. They have developed some interesting similarities despite differences in their original goals and institutional set-up. Not only do the Arab League, the EU, ASEAN, ECOWAS and Mercosur aspire to deeper forms of trade and monetary integration, for instance by seeking to turn their free trade area into a customs union or a common market and to harmonize their monetary policies (Spielau 2012). They have also taken on new tasks in the realm of external and internal security, dealing with issues such as nuclear non-proliferation, disarmament, territorial disputes, domestic political stability, migration, terrorism, or human trafficking. Even the North American Free Trade Area (NAFTA) has 
developed some albeit rudimentary forms of security cooperation (terrorism, drugs, and migration) in the aftermath of September 11, 2001.

\subsection{Persisting Diversity or Emerging Similarity?}

States are still reluctant to delegate political authority to regional organizations. But they have agreed to formalize decision-making procedures, opening them for majority decisions, and to set-up enhanced dispute-settlement procedures, which may take the form of courts or tribunals. While legislative authority firmly remains in the hands of national governments, the powers of executive bodies have been strengthened, and in some cases, parliamentary assemblies with consultative status have been created (Koitsch 2012; Korte 2012; Krome 2012; Hummel/Lohaus 2012). These institutional changes have emerged over a long period of time although the intensity and speed of reforms have increased in the last two decades. While regional institutions do not converge towards a particular model, they show increasing similarities, with regard to the delegation of new policy competencies as well as of executive and adjudicative authority (Table 2). At the same time, important differences remain.

The member states of MERCOSUR, ASEAN and the LAS have not been willing to match the delegation of political authority witnessed in the EU or ECOWAS (Hummel/Lohaus 2012; Koitsch 2012; Kanthak 2012; Goltermann 2012). ECOWAS and the African Union, by contrast, even acquired the coercive power to militarily intervene in their member states which the EU still lacks (Striebinger 2012). The judicial authority of the North American Free Trade Area (NAFTA) with regard to dispute-settlement is not matched by any legislative and or executive authority (Kanthak 2012; Korte 2012).

Table 2: The Progressing Delegation of Policies and Political Authority

\begin{tabular}{|l|l|l|l|l|l|l|}
\hline & $\begin{array}{l}\text { League of Arab } \\
\text { States }\end{array}$ & $\begin{array}{l}\text { European } \\
\text { Union }\end{array}$ & ASEAN & OWAS & Mercosur & NAFTA \\
\hline $\begin{array}{l}\text { Establish- } \\
\text { ment }\end{array}$ & 1945 & 1951 & 1967 & 1975 & 1991 & 1994 \\
\hline $\begin{array}{l}\text { Major } \\
\text { reforms }\end{array}$ & 1950 & 1957 & 1976 & 1993 & 1992 & 2005 \\
& 1957 & 1986 & 2003 & 1999 & 1994 & \\
& 1964 & 1992 & 2007 & 2005 & 1998 & \\
& 1976 & 1998 & & 2006 & 2002 & \\
& 1997 & 2000 & & & & \\
\hline
\end{tabular}




\begin{tabular}{|c|c|c|c|c|c|c|}
\hline & $\begin{array}{l}\text { League of Arab } \\
\text { States }\end{array}$ & $\begin{array}{l}\text { European } \\
\text { Union }\end{array}$ & ASEAN & OWAS & Mercosur & NAFTA \\
\hline \multicolumn{7}{|l|}{ Policies } \\
\hline Economic & $\begin{array}{l}\text { Economic Unity } \\
\text { Agreement } \\
\text { (1957) } \\
\text { Arab Common } \\
\text { Market (1964) } \\
\text { Arab Monetary } \\
\text { Fund (1976) } \\
\text { Greater Arab } \\
\text { Free Trade Area } \\
\text { (1997) }\end{array}$ & $\begin{array}{l}\text { Customs Union } \\
\text { and Common } \\
\text { Market (1957) } \\
\text { Economic and } \\
\text { Monetary Uni- } \\
\text { on (1992) }\end{array}$ & $\begin{array}{l}\text { ASEAN Free } \\
\text { Trade Area } \\
(1992) \\
\text { ASEAN Econo- } \\
\text { mic Community } \\
(2003)\end{array}$ & $\begin{array}{l}\text { Customs Union } \\
\text { and Common } \\
\text { Market (1975) } \\
\text { Fund for Coopera- } \\
\text { tion, Compensati- } \\
\text { on and Develop- } \\
\text { ment (1975) } \\
\text { Economic and } \\
\text { Monetary Union } \\
\text { (1993) } \\
\text { ECOWAS Bank } \\
\text { for Investment } \\
\text { and Development } \\
\text { (1993/99/01) }\end{array}$ & $\begin{array}{l}\text { Common Mar- } \\
\text { ket (1991) }\end{array}$ & $\begin{array}{l}\text { Free Trade Area } \\
\text { (trade and invest- } \\
\text { ment) } \\
\text { North American } \\
\text { Agreement on } \\
\text { Environmental Co- } \\
\text { operation (NAAEC) } \\
\text { North American } \\
\text { Agreement on } \\
\text { Labor Cooperation } \\
\text { (NAALC) }\end{array}$ \\
\hline Security & $\begin{array}{l}\text { Arab Collective } \\
\text { Security (1950) }\end{array}$ & $\begin{array}{l}\text { European Politi- } \\
\text { cal Cooperation } \\
\text { (1981) } \\
\text { Common } \\
\text { Foreign and } \\
\text { Security Policy } \\
\text { (1992) } \\
\text { European Secu- } \\
\text { rity and Defense } \\
\text { Policy (1999) } \\
\text { Common Defen- } \\
\text { se and Security } \\
\text { Policy (2009) }\end{array}$ & $\begin{array}{l}\text { Zone of Peace, } \\
\text { Freedom and } \\
\text { Neutrality } \\
\text { Declaration } \\
\text { (ZOPFAN, 1971) } \\
\text { ASEAN Regional } \\
\text { Forum (1994) } \\
\text { ASEAN+3 (1997) }\end{array}$ & $\begin{array}{l}\text { Protocol on Non- } \\
\text { Aggression (1978) } \\
\text { Protocol on Mu- } \\
\text { tual Assistance in } \\
\text { Defence (1981) } \\
\text { Regional Security } \\
\text { (1993) } \\
\text { Protocol relating } \\
\text { to the Mechanism } \\
\text { for Conflict Pre- } \\
\text { vention, Manage- } \\
\text { ment, Resolution, } \\
\text { Peace-Keeping } \\
\text { and Security } \\
\text { (1999) }\end{array}$ & $\begin{array}{l}\text { Zone of Peace } \\
\text { Declaration } \\
\text { (1999) }\end{array}$ & $\begin{array}{l}\text { Security and Pros- } \\
\text { perity Partnership } \\
\text { (2005) }\end{array}$ \\
\hline $\begin{array}{l}\text { Political- } \\
\text { constituti- } \\
\text { onal }\end{array}$ & & $\begin{array}{l}\text { Justice and } \\
\text { Home Affairs } \\
\text { (1992) }\end{array}$ & $\begin{array}{l}\text { Democracy and } \\
\text { human rights } \\
\text { (2007) }\end{array}$ & $\begin{array}{l}\text { Declaration on } \\
\text { Political Principles } \\
\text { (1991) } \\
\text { Democracy and } \\
\text { human rights } \\
\text { (1993) } \\
\text { Protocol on } \\
\text { Democracy and } \\
\text { Good Governance } \\
\text { (2001) }\end{array}$ & $\begin{array}{l}\text { Democracy and } \\
\text { human rights } \\
\text { (1998) }\end{array}$ & \\
\hline \multicolumn{7}{|l|}{ Authority } \\
\hline $\begin{array}{l}\text { Administra- } \\
\text { tion }\end{array}$ & $\begin{array}{l}\text { General-Secre- } \\
\text { tariat (1945) }\end{array}$ & $\begin{array}{l}\text { General Sec- } \\
\text { retariat of the } \\
\text { Council (1951) } \\
\text { High Authority/ } \\
\text { European Com- } \\
\text { mission (1951) }\end{array}$ & $\begin{array}{l}\text { ASEAN Secreta- } \\
\text { riat (1976) }\end{array}$ & $\begin{array}{l}\text { Executive Secreta- } \\
\text { riat (1975) } \\
\mathbb{Z} \\
\text { ECOWAS Commis- } \\
\text { sion (2006) }\end{array}$ & $\begin{array}{l}\text { Mercosur-Sec- } \\
\text { retariat (1991) }\end{array}$ & $\begin{array}{l}\text { National Secreta- } \\
\text { riats }\end{array}$ \\
\hline
\end{tabular}




\begin{tabular}{|c|c|c|c|c|c|c|}
\hline & $\begin{array}{l}\text { League of Arab } \\
\text { States }\end{array}$ & $\begin{array}{l}\text { European } \\
\text { Union }\end{array}$ & ASEAN & OWAS & Mercosur & NAFTA \\
\hline $\begin{array}{l}\text { Decision- } \\
\text { Making }\end{array}$ & $\begin{array}{l}\text { Council of the } \\
\text { League (1945) } \\
\text { Joint Defense, } \\
\text { Council (1950) } \\
\text { Permanent Mi- } \\
\text { litary Commissi- } \\
\text { on (1950) } \\
\text { Economic Coun- } \\
\text { cil (1950) } \\
\text { Arab Transitio- } \\
\text { nal Parliament } \\
\text { (2004) }\end{array}$ & $\begin{array}{l}\text { European Coun- } \\
\text { cil and Council } \\
\text { of Ministers } \\
\text { (1951) } \\
\text { European Parli- } \\
\text { ament (1951) }\end{array}$ & $\begin{array}{l}\text { ASEAN-Summit } \\
\text { (1976) } \\
\text { Community } \\
\text { Councils of Eco- } \\
\text { nomics, Political } \\
\text { Security and } \\
\text { Socio-Cultural } \\
\text { Affairs (2003) } \\
\text { ASEAN Inter- } \\
\text { Parliamentary } \\
\text { Organization } \\
\text { (1977/2007) }\end{array}$ & $\begin{array}{l}\text { Authority of } \\
\text { Heads of States } \\
\text { and Council of } \\
\text { Ministers (1975) } \\
\text { ECOWAS Parlia- } \\
\text { ment (1993) }\end{array}$ & $\begin{array}{l}\text { Council of the } \\
\text { Common Mar- } \\
\text { ket (1992) } \\
\text { Joint Parliamen- } \\
\text { tary Commissi- } \\
\text { on (1994) } \\
\mathbb{Z} \\
\text { Mercosur Parli- } \\
\text { ament (2005 }\end{array}$ & \\
\hline $\begin{array}{l}\text { Implemen- } \\
\text { tation }\end{array}$ & & $\begin{array}{l}\text { High Authori- } \\
\text { ty/European } \\
\text { Commission } \\
(1951 / 57)\end{array}$ & $\begin{array}{l}\text { ASEAN } \\
\text { Coordinating } \\
\text { Council and } \\
\text { the Community } \\
\text { Councils }\end{array}$ & $\begin{array}{l}\text { Executive Secreta- } \\
\text { riat (1975) } \\
\text { ECOWAS Commis- } \\
\text { sion (2006) }\end{array}$ & $\begin{array}{l}\text { Common } \\
\text { Market Group } \\
\text { (1992) } \\
\text { Mercosur Trade } \\
\text { Commission } \\
(1994)\end{array}$ & $\begin{array}{l}\text { Free Trade Com- } \\
\text { mission } \\
\text { Commission for } \\
\text { Environmental } \\
\text { Cooperation } \\
\text { Commission for } \\
\text { Labor Cooperation }\end{array}$ \\
\hline $\begin{array}{l}\text { Adjudica- } \\
\text { tion }\end{array}$ & & $\begin{array}{l}\text { European Court } \\
\text { of Justice (1951) }\end{array}$ & $\begin{array}{l}\text { Dispute-settle- } \\
\text { ment mecha- } \\
\text { nism (1996) } \\
\mathbb{Z} \\
\text { Enhanced Dis- } \\
\text { pute Settlement } \\
\text { Mechanism } \\
\text { (2004) }\end{array}$ & $\begin{array}{l}\text { Arbitrary Tribunal } \\
\text { (1975) } \\
\text { Community Court } \\
\text { of Justice (1993) }\end{array}$ & $\begin{array}{l}\text { Dispute-settle- } \\
\text { ment procedure } \\
\text { (1991) } \\
\text { Permanent } \\
\text { Review Court } \\
\text { (2002) } \\
\text { Administrative } \\
\text { Labour Court } \\
\text { (2003) }\end{array}$ & $\begin{array}{l}\text { Dispute Settlement } \\
\text { Procedure }\end{array}$ \\
\hline
\end{tabular}

In sum, rather than the emergence of new forms of regionalism, there is a bifurcation between (rather classical) regional cooperation, on the one hand, and regional integration, on the other. While shallow economic regionalism based on intergovernmental cooperation seems to proliferate, already existing forms of regionalism have not only moved towards regional integration by deepening and broadening; they have also developed some institutional similarities. This bifurcation has been largely overlooked since different bodies of literature have focused on different forms of regionalism. Moreover, these developments raise the question to what extent regionalism differs between regions not only with regard to outcomes but also its major drivers. Do states respond to a common demand for (enhanced) delegation of policies and political authority emanating from the challenges of globalization and transnationalization that is best satisfied at the regional level? Are regional institutions supplied by powerful states to pursue their national interests in market access and political stability of their "backyards"? Or is regionalism part of a global script which diffuses depicting regional institutions as effective and legitimate governance structures in the 21 st century? 


\section{The Drivers of Regionalism: Old Theories and New Puzzles}

The IR literature offers a multitude of approaches to regionalism. However, no single theory could possibly account for the variation in outcomes. International Political Economy (IPE) has mostly been concerned with economic regionalism explaining the emergence and evolution of preferential and free trade areas (shallow economic regionalism). In line with the general IR literature, IPE text books are organized around four major theoretical perspectives on regionalism, which draw on neo-realism, neoliberal institutionalism, social constructivism and Marxism-structuralism, respectively. While they offer important insights, these schools of thought are less appropriate to study broader and deeper forms of regionalism that involve the delegation of political authority across a wider range of issues.

Theories of European integration had to move beyond economic regionalism and developed explanations for the progressive delegation of political authority and policies to the supranational institutions of the European Union also in other areas than market integration. Yet, neofunctionalism and liberal intergovernmentalism (and their various offsprings) have only partially been able to account for the process and outcome of European integration. Nor do they travel easily to other regions of the world which do not share the same level of economic development and interdependence and are more heterogeneous with regard to their political regimes.

Since the literature has focused on different forms of regionalism, the scope of the various approaches is limited and there is no theory that could possibly account for the two empirical trends we observe. Yet, theories in IPE, IR, EU and Area Studies have identified important causes of regionalism, which deploy significant, albeit varying explanatory power across the globe. The next section will organize the various bodies of literature around major drivers of regionalism, which are distinguished as demand- and supplydriven factors (for a similar approach see Mattli 1999a: 41-43). Their causal effects can follow either an instrumentalist (rationalist) or a norm-based (sociological) logic of social action. Such a factor-oriented approach should facilitate comparative research across regions and help engage the various bodies of literature.

\subsection{The Demand for Regionalism. It Is Not Only the Economy, Stupid!}

Rationalist approaches have predominantly focused on explaining economic regionalism. They point to expected (material) gains as the main drivers of the demand for (more) regionalism. Theories differ, then, with regard to what these gains exactly are. Economists emphasize welfare enhancing effects, which tend to be greater among geographically proximate states. These include reduced transaction costs, economies of scale, technological innovation due to greater competition, more foreign direct investments and greater economic and political weight in international markets and institutions (cf. Mattli 1999b: 46f; Hancock 2009: 25-29). Accordingly, globalization becomes a major driver for economic regionalism since global markets entail increased transborder mobility and economic linkages and trade issues are less cumbersome to deal with at the regional than at the multilateral level (Schirm 2002). Coping with negative externalities, such 
as diversions of trade and investment, provides another rational to pursue economic regionalism. States may either seek membership in regional institutions generating the external effects as many European countries have done in the case of the EU and some of the South American countries do with NAFTA (Mattli 1999b: 59-61). Or they create their own regional group. NAFTA can be interpreted as the US' reaction to the fortification of the Single European Market and the emerging economic regionalism in Asia (Mattli 1999b: 183-185). A similar "domino effect" (Baldwin 1995) was triggered by the US' turn towards regionalism which has contributed to the proliferation of regional PTA, since states perceived the US as no longer capable of or willing to ensure the stability of the global trading system (Mansfield 1998). The decision of 1992 to complement the ASEAN security community with an ASEAN free trade area is partly explained by concerns over the global positioning of ASEAN markets vis-à-vis NAFTA and the Single European Market (Means 1995).

Neofunctionalist and liberal intergovernmentalist approaches provide more "liberal", society-centered explanations for economic regionalism. The demand is fueled by those domestic interests that tend to benefit from (more) free trade and liberalization more broadly speaking. While functionalism assumed a general demand for regionalism as a means of technocratic problem-solving across borders, neofunctionalists emphasize the role of interest groups, professional associations, producer groups and labor unions, which do not equally benefit from regionalism. Those who benefit form transnational coalitions with likeminded groups from other member states and ally with regional actors. Thus, European companies joined forces with the European Commission to propel the Single European Market and the European Currency (Sandholtz/Zysman 1989; Cowles 1995), and American business forcefully lobbied in favor of the NAFTA and APEC agreements (Milner 1995; Cameron/Tomlin 2002).

Liberal intergovernmentalism and second image approaches to International Relations also take economic and social interests as the starting point of the demand for economic regionalism (Rogowski 1989; Solingen 1998; Hiscox 2006; Frieden 2002; Moravcsik 1997). Yet, these interests are channeled through the domestic political process of interest aggregation and interest representation rather than transnational channels. States are the master of regional organizations and gate-keep access to international decision-making processes. Domestic interest groups may try to circumvent them by forming transnational alliances but when push comes to shove they have to rely on their governments if they want to influence regional policy outcomes and institutional reforms (Moravcsik 1998). Depending on their access to domestic decision-making processes and their action capacity, pro-integration interests are more or less successful in making their political demand for regional integration heard (Rogowski 1989; Milner 1997).

Rationalist society-centered theories, which focus on preferences in domestic and transnational society to generate the demand for economic regionalism explicitly or implicitly, presuppose liberal democracy and advanced market economy as context conditions for regionalism to unfold. Societal interests are unlikely to form and mobilize in favor of regionalism in authoritarian or semi-authoritarian countries with low levels of socio-economic development and/or low levels of economic and social transactions (Haas 1961; Haas/Schmitter 1964). This "liberal" bias limits the applicability of society-centered theories to the OECD world of industrialized liberal democracies; they have a harder time to explain economic regionalism in other parts of the world. Moreover, societal demand is hardly sufficient - it takes political leadership and international institutions to propel regionalism (see below). 
While rationalist approaches start from different levels of analysis, they take economic regionalism as a strategic response of states and economic actors to the challenges of globalization. The demand is hence driven by economic interdependence. Variation in (institutional) outcomes is explained by the higher degree of economic interdependence fueling the demand for regional institutions to settle resulting conflicts (Mansfield 1998; Mansfield/Milner 1997; Mattli 1999b; Moravcsik 1998; Stone Sweet/Caporaso 1998), the level of uncertainty, the nature of the problem, the number of actors and the asymmetry between them (Stein 1983; Koremenos et al. 2001, 2004). Geographic proximity and democracy seem to increase the intensity of economic exchange between countries, and hence foster regional cooperation (Mansfield et al. 2000). Such rationalist-interest based reasoning has been extended to political and security regionalism focusing on so-called spill-over effects, on the one hand, and other benefits than increasing trade and investment, on the other.

(Neo)functionalist approaches do not only provide an explanation for progressing economic regionalism by societal demand. Economic regionalism is also a means to overcome the resistance of national governments against the delegation of policies and political authority in the areas of defense and war, currency and domestic law and order, which lie at core of state sovereignty (Mitrany 1966: 25; Haas 1967: 323; Lindberg/Scheingold 1970: 263-266). The link between economic, political and security regionalism is the so-called "functional spill-over" (Haas 1958). Member states are willing to delegate policy tasks and political authority on economic issues of lower salience. Once the process is set into motion, however, further delegation is required in order to maintain and increase the economic benefits. Liberalizing trade not only leads to greater flows in goods but also in capital, services and people, which are still subject to national control reducing the economic gains of transborder transactions. Therefore, the EU has subsequently removed national barriers to the free movements of goods, services, capital, and labor. This process has not been limited to legal, technical, and fiscal barriers but has also led to the increasing elimination of physical border controls. The Europe without borders, however, has given rise to significant problems for internal security, caused by illegal immigration, organized crime, and transnational terrorism. As a result, the member states gave the EU the authority to legislate on a whole range of internal security issues, including visa, migration, asylum, criminal prosecution, and law enforcement. The spill-over from economic to security regionalism evolved over a period of more than 40 years. Moreover, the EU member states remain reluctant to delegate authority to the EU when it comes to external security; unlike justice and home affairs, foreign and defense policy is still largely intergovernmental (cf. Börzel 2005). While neofunctionalist approaches have a hard time to explain the gap between internal and external security integration, the EU is a prime example of how economic regionalism fosters political and security regionalism among states that engage in mutual economic exchange.

The delegation of economic and security policies to regional institutions can also be explained by political rather than economic rationalities. Milward argued that national governments seek to isolate political decisions with redistributional consequences from particularistic domestic interests by transferring them to the EU level (Milward 1992; cf. Moravcsik 1998). Unlike neofunctionalist reasoning, the political rationale also applies in regions that lack economic interdependence as a major driver for regionalism. African, Latin American, Arab and Asian leaders have supported regionalism as a source of domestic power and consolidation of national sovereignty (Herbst 2007; Okolo 1985; Nesadurai 2008; Barnett/Solingen 2007; Morales 2002). Weak states, in particular, should be more inclined to engage in "regime-boosting 
regionalism" (Söderbaum 2004) because they are more dependent on economic growth to forge domestic stability, tackle societal problems, and strengthen their international standing in terms of bargaining power and legitimacy (Aschhoff 2012). Moreover, non-state actors can more easily circumvent their governments in seeking transnational exchange (Bach 2005). Yet, states must not be too weak either-political instability can be a major obstacle to regionalism (Edi 2007). Furthermore, the lack of state capacity creates serious issues for the effectiveness of regional organizations when it comes to compliance with regional norms and rules (Goltermann 2012). The same ambivalence can be found for neo-patrimonialism. While regional organizations provide governments with additional perks for buying-off the loyalty of their clients (Kirschner/ Stapel 2012), regionalism can also curb resources, e.g. by decreasing tariff revenues (Allison 2008; Collins 2009). Finally, regionalism has served as a tool for settling conflicts and securing peace among (former) rival nations (Oelsner 2004; Acharya 2001; Francis 2006; Gruber 2000) and, more recently, for consolidating and promoting democracy in its member states (Pevehouse 2005; Ribeiro Hoffmann/van der Vleuten 2007). What national governments lose in authority to regional institutions, they gain in problem-solving capacity, particularly since many societal problems, such as environmental pollution, pandemics, drug trafficking or migration, are no longer confined to the boundaries of the nation-state.

Constructivist approaches put ideas, norms, identities, and discourses as ideational drivers of regionalism center stage. Long before the constructivist turn in IR, transactionalism argued that successful integration requires a sense of community (Deutsch et al. 1957; Adler/Barnett 1998; Acharya 2001). It is unclear, however, whether collective identity is a precondition for or rather an indicator of regional integration. Students of European integration still argue to what extent the EU has built a common identity and what it is based upon (Risse 2010). While the sense of community is weaker in North America, Africa, the Middle East or Asia, the question remains whether this is because states are so diverse with regard to their political systems, societal structures and cultures that there is no demand for (stronger) common institutions (Barnett/Solingen 2007). Or are regional institutions not strong enough to breed a community (Clarkson 2008; Acharya 2005; Jones/Smith 2007; Barnett 1995; Okolo 1985)?

While the IPE and the European Integration literature focus on different forms of regionalism, they both offer convincing arguments why states should delegate policy tasks and authority to regional institutions in the first place. They are less compelling in explaining the differential outcomes we find across different regions. Economic interdependence has been a key driver of economic regionalism both in Europe and North America. But why have the European states opted for subsequently deepening and widening the EU while the US, Canada and Mexico concluded a "complete contract" (Cooley/Spruyt 2009), which does not preview any further delegation of policies and political authority to NAFTA (Kanthak 2012)? Why do we find a gap in the delegation of authority between internal and external security in the EU (Börzel 2005)? Why have some of the African countries in absence of any economic interdependence delegated more political authority to regional institutions than the EU member states? Likewise, why have China, Japan and South Korea not been willing to set-up any regional institutions despite their high levels of economic exchange? 


\subsection{The Supply of Regionalism. Interests, Power, and Norms}

Rationalist approaches tend to assume that demand is sufficient for regionalism to emerge. At the same time, regime theory and neoliberal institutionalism contend that international cooperation requires political leadership and international institutions to work. Setting-up institutions to overcome market failures and collective action problems involves costs, too, and may create a(nother) collective action problem. The rationalist solution is political or hegemonic leadership. For neofunctionalism, regional bureaucracies, such as the European Commission, are most likely to exercise the necessary leadership to translate social demands into reforms of regional institutions. Supranational actors are the natural ally of interest groups in overcoming the resistance of national governments to delegate political authority and additional tasks to the regional level (Haas 1958; Lindberg 1963). Legal approaches and the so-called supranational institutionalists emphasize the role of centralized dispute-settlement bodies and their judicialization as engines of regional integration (Burley/Mattli 1993; Stone Sweet/Sandholtz 1998a; Stone Sweet 2000).

Hegemonic stability theory, by contrast, points to powerful states, which are willing to and capable of acting as "regional paymaster, easing distributional tensions and thus smoothing the path of integration" (Mattli 1999a: 56; cf. Gilpin 1987: 87-90; Yarbrough/Yarbrough 1992). Yet, they supply regionalism for different reasons. The US, China, Russia, South Africa or Nigeria supported and engaged in region-building for their geostrategic and economic interests in strengthening military alliances, promoting stability in neighboring countries, or securing access to new markets, cheap labor, water, and energy resources (Antkiewicz) Whalley 2005; Gowa 1994; Clarkson 2008; Coleman 2007: 155-184). The US played a key role in the creation and prevalence of the European Community and ASEAN by mitigating the security dilemma in the region (Gruber 2000; Acharya 2001). It has also acted as a regional hegemon for NAFTA to counterbalance the Single European Market (Clarkson 2008). Likewise, Brazil and Venezuela have championed MERCOSUR to establish itself as a regional power and to contain US influence in Latin America (Gomez Mera 2005; Tussie 2009; Hummel/Lohaus 2012). A similar competition for containing external and exercising regional hegemonic power through promoting (different forms of) regionalism can be observed between Iraq and Egypt in the League of Arab States (Khadduri 1946), Malaysia and Indonesia in ASEAN (Dent 2008: 86-88), Japan and China in East Asia (Beeson 2006), Nigeria and South Africa in Sub-Saharan Africa (Francis 2006), and Russia and Uzbekistan in Central Asia (Kubicek 1997; Wirminghaus 2012). Regional powers can be engines of integration, as France and Germany have been in the EU and Brazil and Argentina are in Mercosur (Porrata-Doria Jr 2005), although the latter have been criticized for not providing sufficient regional leadership (Mattli 1999a: 160). Conversely, the absence or ineffectiveness of regionalism in the Middle East or Asia is often blamed on the absence of a regional or external hegemon (Fawcett/Gandois 2010; Hemmer/ Katzenstein 2002).

While using regionalism to establish and affirm their regional hegemony, powerful states are reluctant to bind themselves by regional institutions. The intergovernmental nature of MERCOSUR and NAFTA and their limited scope of regional integration are largely explained by the unwillingness of Brazil and the US to delegate authority to regional institutions (Hummel/Lohaus 2012; Kanthak 2012). At the same time, the US has agreed to a highly legalized and inflexible agreement that does not leave much levy to the member states. This degree of self-binding goes far beyond what other regional powers have committed to and poses a puzzle to power-based approaches. Powerful states do not always get what they want as the case 
of Nigeria in ECOWAS seems to suggest (Striebinger 2012). Brazil has to compromise with Argentina since the US provides an exit option for the latter. Interpresidentialism plays a key role in the functioning of MERCOSUR (Hummel/Lohaus 2012). Leadership by government diplomacy provides a functional equivalent for regional institutions, not only in MERCOSUR but also in ASEAN through the so-called ASEAN way (Kanthak 2012). Finally, power-based theories of regionalism have little on offer to explain the differential commitment of small states. Paraguay, Uruguay, Mexico and Canada may seek to bind their regional hegemon (Hummel/Lohaus 2012; Kanthak 2012; Spielau 2012). However, by joining MERCOSUR and NAFTA, respectively, they also become (even) more vulnerable to its dominance. Moreover, why is it that some former Soviet republics decided to bandwagon with Russia and Uzbekistan while others engaged in attempts to counterbalance their regional dominance (Wirminghaus 2012)?

Constructivist approaches have featured less prominently in explaining the supply of regional institutions. Hemmer and Katzenstein have argued that the US was less enthusiastic to exercise hegemonic leadership in Asia than in Europe because of the lower cultural affinity (Hemmer/Katzenstein 2002; Katzenstein 2005). Cultural difference is also to account for the distinct approach ASEAN states have taken towards regional integration. The "ASEAN way", which is based on informal consensus-building, organizational minimalism, and thin institutionalization, is incompatible with Western models of legalized institutions (Acharya 2004; Katzenstein 2005; Nesadurai 2009). Such explanations have an essentialist flavor and lose a lot of their explanatory power when applied across regions. More importantly, social constructivism has to offer more general explanations for why, when and where regionalism emerges focusing on processes of diffusion.

The supply of regional institutions can stem from other regions or international actors, which actively promote or passively provide blue-prints for region-building. "Pax Americana" and "Pax Europaea" are two "global scripts" (Meyer et al. 1992) on regionalism. The first one is based on regional trade cooperation promoted by the US and international organizations, including the World Trade Organization, the World Bank, and the International Monetary Fund (Grugel 2004). The second is advocated by the EU, striving for regional integration, which is broader in scope and infringes more strongly on the sovereignty of states (Börzel/Risse 2009). As we have seen in the previous section, there are interesting institutional similarities among major regional organizations, which are not easily explained by functionalist approaches. Market or problem pressures may increase the demand for (more) regional institutions. But even if certain institutions effectively serve specific functions and help solve similar problems, states always have choices. Institutions can be "contagious" (Levi-Faur 2005) under conditions of uncertainty, policy failure and dissatisfaction with the status quo. Regional organizations that struggle to become more effective may look to other organizations that are considered as success cases for policies and rules that effectively solved similar problems and are transferable into their context (Meyer/Rowan 1977; Dolowitz/Marsh 2000). Next to lesson-drawing, regions may also emulate others for normative reasons, to increase their legitimization (symbolic imitation; see Polillo/Guillén 2005) or to simply imitate their behavior because its appropriateness is taken for granted (mimicry; see Haveman 1993; Meyer/Rowan 1977). Seeking international legitimacy and signaling commitment to trade liberalization motivated ASEAN to set-up a dispute settlement mechanism (DSM) that has been hardly used so far (Korte 2012). Emulation also might be driving the recent deepening and broadening of ASEAN, whose new Charta bears some striking resemblance with EU institutions (Jetschke 2010; Katsumata 2009). Likewise, ECOWAS and LAS might be following a global script that entails the establishment of certain regional institutions and for which, at least in the case of ECOWAS, the EU provides 
a reference model (Koitsch 2012). With the establishment of the Euro, the EU has become an example to follow for countries in Latin America, Africa and Asia, which may defy supranationalism but see a common currency as an anchor of regional stability (Lorca-Susino 2010). Whether the EU will continue to inspire other regions to seek economic and monetary integration will depend on the EU mastering the current financial crisis. Will the EU deepen integration and develop common economic and fiscal policies or will its member states relapse in defensive nationalism as they did during the oil crisis in the early 1970 ?

The comparative evaluation of mainstream theories reveals important drivers of regionalism. None of them is capable of fully explaining variation across time and regions. Nor have they much to say about why such diverse regional organizations as LAS and ECOWAS appear to develop similar institutions. Yet, the different drivers could be combined as long as their ontological assumptions are compatible. The theoretically consistent rather than eclectic combination of demand and supply variables sheds new light on old puzzles and gives rise to new questions. It remains to be seen to what extent it will form the basis for new approaches that can account for the spread of shallow economic regionalism, on the one hand, and the deepening and widening of existing forms of regionalism, on the other.

\section{When Regionalism Hits Home. Policy Harmonization and Structural Change}

\subsection{From Second Image Reversed...}

Second image reversed approaches in IR explore the impact of the international system upon domestic politics (Gourevitch 1978). They have made little headway in comparative regionalism. Economists have explored the economic effects of regional free trade agreements on trade and investment flows, economic growth, poverty, and social inequality (Weintraub 2004; Preusse 2004; Musila 2005). Their impact on domestic policies, institutions, and political processes has remained largely ignored. Studies have looked for policy harmonization in different sectors for individual countries, particularly in the case of NAFTA. The literature has also started to explore processes of "differential empowerment" in the case of subnational actors (regional and local authorities, companies, civil society organizations) through their access to new markets and policy-making arenas (Aspinwall 2009; Acharya 2001: 48). Yet, the findings are hardly generalizable and seldom guided by theoretical considerations.

A noticeable exception is the study of Jon Pevehouse, who explores the effect of regional organizations on democratization (Pevehouse 2005; cf. Anderson 1999). He argues that the "democratic density" of regional organizations is associated with the democratic consolidation of their members due to conditionality and assistance. ECOWAS can even invoke military coercion to prevent coup d'états (Striebinger 2012). Governments of young democracies can bind themselves and their successors to political liberalization and democratic norms by external commitment (Pevehouse 2005: 37; Mansfield/Pevehouse 2006; Moravcsik/ Vachudova 2003). Democracies do not only show greater commitment to regional organizations (Kirschner/ Stapel 2012). Joining a democratic regional organization significantly decreases the probability of democratic breakdown (Pevehouse 2005; Pirzer 2012), even though it may require a regional hegemon and/ or international and domestic pressure to make the regional organization actively intervene (Striebinger 2012). 
IPE and Compliance research have more generally investigated the role of international institutions for domestic change. After all, international organizations, such as the World Bank and the International Monetary Fund, substantially interfere with the governance institutions of developing countries. Likewise, most regional organizations can use conditionality to promote structural adjustments by promising or granting additional benefits, such as financial and technical assistance, loans, debt relief, or membership in an organization conditional. Or they incur costs through economic and diplomatic sanctions. "Reinforcement through reward" (Schimmelfennig/Sedelmeier 2006) or "correction through punishment" offer the opportunity for a redistribution of resources among domestic actors empowering those who push for domestic change (Risse et al. 1999; Milner 1988; Rogowski 1989). Alternatively, regional organizations can resort to political dialogue and other instruments of socialization, which seek to change actors' behavior through persuasion and learning, often with the help of change agents or entrepreneurs (Finnemore 1993; Finnemore/Sikkink 1998; Checkel 2005; Kelley 2004a). Conditionality and political dialogue both aim at influencing the choice of actors, be they informed by cost-benefit calculations or guided by normative concerns about socially accepted behavior. They thus contrast with coercion and assistance, which are not captured by the two general logics of domestic change. While coercion does not leave actors any choice, assistance provides unconditional financial and technical aid that shall enable actors to make choices in the first place.

The workings of these causal pathways through which regional organizations may impact upon the domestic structures of their members have so far only been systematically explored for the case of the EU.

\section{2 ... to Europeanization and Domestic Change}

In the 1990s, students of European integration became increasingly interested in how the member states responded to the impact of European policies, processes, and institutions. ${ }^{8}$ The first generation of such "top-down" studies focused on the consequences of European integration for the autonomy and authority of the member states. In order to theorize the domestic impact of Europe, the explanatory logics of the two major paradigms of European integration were essentially turned around. If intergovernmentalist approaches were correct in assuming that member state governments controlled European integration while supranational institutions themselves exercised little independent effect, the power of the member states would not be challenged. Rather, European integration should enhance the control of national governments over domestic affairs since it removed issues from domestic controversy into the arena of executive control at the European level (Milward 1992; Moravcsik 1994). Proponents of neofunctionalist or supranationalist approaches suggested exactly the opposite, namely that European integration provided domestic actors, such as regions and interest groups, with independent channels of political access and influence at the European level enabling them to circumvent or by-pass their member states in the EU policy process (Marks 1993; Marks et al. 1996). Between the two competing paradigms, a third group of scholars emerged that rejected the zero-sum game conception of the relationship between the EU and its

8 Economists, of course, have been more interested in the economic effects of European integration; see e.g. Winters/Venables 1991. 
member states, in which one level was to be empowered at the expense of the other. They argued that the different levels of government would become increasingly dependent on each other in European policymaking. As a result, European integration would neither strengthen nor weaken but transform the member states by fostering the emergence of cooperative relationships between state and non-state actors at the various levels of government (Kohler-Koch 1996; Rhodes 1996; Kohler-Koch/Eising 1999).

In recent years, the "top-down" literature has grown significantly and developed its own approaches to analyzing the effect of the evolving European system of governance on the member states (cf. Cowles et al. 2001; Featherstone/Radaelli 2003; Bulmer/Lequesne 2005; Graziano/Vink 2006). Most studies agree that member state responses to Europeanization are differential, i.e. differ across policy sectors, institutions, and time. While EU policies and institutions are an impetus of domestic change that is a constant for all member states, they have facilitated domestic reforms but not necessarily led to convergence of national polities, politics, or policies. To solve the empirical puzzle, the literature has drawn on two different strands of institutionalist thinking. Rationalist and constructivist approaches of Europeanization both assume that the misfit between European and domestic policies, institutions and political processes constitutes a necessary condition for domestic change and that institutions mediate or filter the domestic impact of Europe, which emanates from pressure of adaptation caused by such misfit. They differ, however, in their assumptions in exactly how institutions matter (cf. Börzel/Risse 2003).

Rational choice institutionalism argues that the EU facilitates domestic change through changing opportunity structures for domestic actors. In a first step, misfit between the EU and domestic norms creates demands for domestic adaptation. It takes agency, however, to translate misfit into domestic change. In a second step, the downloading of EU policies and institutions by the member states are shaped by cost/ benefit calculations of strategic actors whose interests are at stake. Institutions constrain or enable certain actions of rational actors by rendering some options more costly than others. From this perspective, Europeanization is largely conceived as an emerging political opportunity structure which offers some actors additional resources to exert influence, while severely constraining the ability of others to pursue their goals. Domestic change is facilitated, if the institutions of the member states do not allow domestic actors to block adaptation to EU requirements through veto points or if, on the contrary, they empower domestic reform coalitions by providing them with additional resources to exploit the opportunities offered by Europeanization.

Other parts of the Europeanization literature draw on sociological institutionalism in order to specify change mechanisms based on ideational and normative processes of Europeanization. Unlike its rationalist counterpart, sociological institutionalism draws on a normative logic of appropriateness which argues that actors are guided by collectively shared understandings of what constitutes proper, socially accepted behavior. These collective understandings and intersubjective meaning structures strongly influence the way actors define their goals and what they perceive as rational action. Rather than maximizing their egoistic self-interest, actors seek to meet social expectations in a given situation. From this perspective, Europeanization is understood as the emergence of new rules, norms, practices, and structures of meaning to which member states are exposed and which they have to incorporate into their domestic structures. If there is such a misfit, it also takes agency for bringing about domestic change. But the ways in which domestic actors facilitate reforms are different. Norm entrepreneurs, such as epistemic communities 
or advocacy networks, socialize domestic actors into new norms and rules of appropriateness through persuasion and social learning who redefine their interests and identities accordingly. The more active norm entrepreneurs are and the more they succeed in making EU policies resonate with domestic norms and beliefs, the more successful they will be in bringing about domestic change. Moreover, collective understandings of appropriate behavior strongly influence the ways in which domestic actors download EU requirements. First, a consensus-oriented or cooperative decision-making culture helps to overcome multiple veto points by rendering their use for actors inappropriate. Second, a consensus-oriented political culture allows for a sharing of adaptational costs which facilitates the accommodation of pressure for adaptation. Rather than shifting adaptational costs upon a social or political minority, the "winners" of domestic change compensate the "losers".

The Eastern enlargement of the EU created a unique opportunity for the next generation of Europeanization research to test the approaches that had emerged to account for the conditions and causal mechanisms through which the EU triggers domestic change. The two logics of Europeanization were applied and adapted to studying the domestic impact of the EU's attempt to transfer its policies and institutions to candidate countries (cf. Schimmelfennig/Sedelmeier 2005; Sedelmeier 2006; Schimmelfennig 2007; Kelley 2004b; Epstein 2008) and increasingly also to its Eastern and Southern neighbors in the former Soviet Union and the Mediterranean, respectively (Lavenex et al. 2007; Lavenex 2008; Schimmelfennig/Scholtz 2009; Börzel 2011; van Hüllen 2012).

Findings on "Accession Europeanization" and "Neighborhood Europeanization" have corroborated the differential impact of Europe. While domestic mediating factors played a less prominent role than in "Membership Europeanization", they did mitigate the domestic impact of accession, particularly beyond the legal implementation of EU policies. In case of the accession countries in Central and Eastern Europe (CEE), the dominance of differential empowerment through conditionality has given rise to concerns about "shallow Europeanization" (Goetz 2005: 262) since sustainable compliance with (costly) EU policies ultimately requires internalization. The CEE countries formally adopted a massive amount of EU legislation, which, however, has often not been properly applied and enforced and thus, has not changed actors' behavior (Falkner et al. 2008; Börzel 2009). The neighborhood countries have largely resisted domestic change. Their deficient democratic institutions and/or their limited state capacity have mitigated and constrained the domestic impact of the EU. High misfit imposing prohibitive costs to incumbent governments, weak to non-existent EU conditionality, the absence of domestic reform coalitions and weak administrative capacities to orchestrate reforms render domestic change induced by Europeanization extremely unlikely (Schimmelfennig/Scholtz 2009; Börzel 2010b; Börzel/van Hüllen 2011).

The literature on Europeanization yields important implications for the internal effects of regionalism in other parts of the world. The European Union certainly is a most likely case in this regard. Not only are EU institutions strong and its policies comprehensive. While member states often face significant misfit, the resonance of EU policies and institutions with their domestic structures is comparatively high. Other regional institutions may be less likely to deploy a transformative effect on their members. Yet, the change mechanisms still apply. Similar to the EU, the Mercosur, ECOWAS, the African Union or ASEAN have increasingly defined institutional requirements for "good governance" which their members have to respect. Next to human rights, the rule of law, democracy and the fight against corruption form part of the governance 
package many regional organizations seek to promote. Moreover, they have developed instruments in trying to shape the governance institutions of their members, which draw on similar causal mechanisms as the Europeanization approaches (Bruszt/McDermott 2009). To what extent regional organizations have had an impact on the governance structures of their members is yet to be explored. The active engagement of ECOWAS and, to a lesser extent, MERCOSUR, in protecting and promoting democratic change still appears to be the exception rather than the rule. Yet, the case of ASEAN demonstrates that regional organizations can also have a less direct and probably more long-term effect, establishing a political opportunity structure that provides civil society actors with rights, money, and networks and entrapping their member states in their commitment to human rights and democracy (Krome 2012). These findings show that processes of "differential empowerment" found in the EU and NAFTA (Aspinwall 2009) also work in other regions.

\section{Conclusions}

This paper has argued that the rise in regionalism does not constitute a new phenomenon. However, what is certainly distinct about regionalism in the 21st century is the extent to which it draws on existing forms. Due to its lasting success, the EU has become an important reference point in Latin America, Africa and Asia, as a model to emulate or to resist (Telò 2001; Farrell 2007; Henry 2007; Katsumata 2009; Jetschke 2010). ${ }^{9}$ The EU itself has sought to supply its institutions in region-to-region dialogue and interregional trade agreements (De Lombaerde/Schulz 2009; Söderbaum/van Langenhove 2006; Farrel 2009). To foster the diffusion of regional governance structures, the EU has drawn on the same set of instruments it has deployed in seeking to change the domestic structures of (prospective) member states and neighboring countries (Börzel/Risse 2009).

The EU's partnership approach contrasts with that of the U.S. whose "hub and-spoke" model entails more asymmetrical relations and is largely restricted to economic regionalism (Grugel 2004; Farrell 2007; Clarkson 2008). To the extent that the U.S. promotes regional cooperation at all, it favors regional free trade areas rather than deeper and broader integration schemes the EU seeks to promote. Whether the EU is really the "hub of a global pattern of interregional relations" (Hettne 2005: 558) from which it seeks to reconstruct a multilateral world order in a regionalized form (multiregionalism), and to what extent this is part of its identity as a civilian or normative power or simply the attempt to expand its (liberal) empire (Manners 2002; Telò 2006; Whitman 1998; Cooper 2003) is another question.

If there is an "emerging regional architecture of world politics" (Acharya/Johnston 2007), the EU is not the only way for regional organizations to improve their effectiveness and legitimacy or shield themselves against external criticism. ECOWAS, for instance, has served as a role model in security integration for other African regional organizations (Holt/Shanahan 2005). While there is certainly not one dominant form, regionalism has become part of a global governance script, in which region-building does not only

9 For a similar debate in the 1960s see Haas 1961; Nye 1965. 
feature as an effective and legitimate way to foster peace and prosperity but which sees "regions as the fundamental, even driving force of world politics" (Fawn 2009).

Regionalism has gained prominence in the 21st century, not only as a form of economic, political, and social organization, but also as a field of study. The debate on the rise of regionalism shows that we need to have a clear understanding of what we mean by regionalism and how we measure it. More than 40 years ago, Joseph Nye complained that "integration theorists have talked past each other" using different concepts and measurements (Nye 1968: 855). His criticism still holds today - there is a Babylonian variety of definitions and analytical frameworks and only a few students of regionalism have engaged in a systematic comparison of different forms around the globe. In some ways, research on old regionalism was more comparative than many studies of new regionalism (see for instance Etzioni 1965; Haas/Schmitter 1964; Nye 1970, 1971). Systematically exploring the genesis, growth, institutional design, and effectiveness of regional organizations across time and space puts mainstream approaches to a serious test and the debate about new regionalism into perspective. There are many "roads to regionalism" (Börzel et al. 2012) and not all of them lead to new forms of regionalism. Regions outside Europe leave much to be explored with regard to why states build, develop, join and leave regional organizations. 


\section{Literature}

Acharya, Amitav 2001: Constructing a Security Community in Southeast Asia, London: Routledge.

Acharya, Amitav 2004: How Norms Spread: Whose Norms Matter? Norm Localization and Institutional Change in Asian Regionalism, in: International Organization 58/2, 239-275.

Acharya, Amitav 2005: Do Norms and Identity Matter? Community and Power in Southeast Asia's Regional Order, in: The Pacific Review 18/1, 95-118.

Acharya, Amitav/Johnston, Alastair lan (eds) 2007: Crafting Cooperation. Regional International Institutions in Comparative Perspective, Cambridge: Cambridge University Press.

Adler, Emanuel/Barnett, Michael (eds) 1998: Security Communities, Cambridge: Cambridge University Press.

Allison, Roy 2008: Virtual Regionalism, Regional Structures and Regime Security in Central Asia, in: Central Asian Survey 27/2, 185-202.

Anderson, Jeffrey (ed.) 1999: Regional Integration and Democracy, Lanham, MD: Rowman \& Littlefield.

Antkiewicz, Agata/Whalley, John 2005: China's New Regional Trade Agreement, in: World Economy 28/10, 1539-1557.

Aschhoff, Niklas 2012: Joining the Neighbors - The Accessions to ASEAN in the 1990s, in: Börzel, Tanja A./ Goltermann, Lukas/Lohaus, Mathis/Striebinger, Kai (eds): Roads to Regionalism. Genesis, Design, and Effects of Regional Organizations, Aldershot: Ashgate.

Aspinwall, Mark 2009: NAFTA-Ization: Regionalization and Domestic Political Adjustment in the North American Economic Area, in: Journal of Common Market Studies 47/1, 1-24.

Aspinwall, Mark/Schneider, Gerald 2000: Same Menu, Separate Tables: The Institutionalist Turn in Political Science and the Study of European Integration, in: European Journal of Political Research 28/5, $1-36$.

Bach, Daniel C. 2005: The Global Politics of Regionalism: Africa, in: Farrell, Mary/Hettne, Bjorn/van Langenhove, Luk (eds): Global Politics of Regionalism.Theory and Practice, London and Ann Arbor, MI: Pluto Press, 171-188.

Balassa, Bela 1973: The Theory of Economic Integration, London: Allen \& Unwin.

Baldwin, Richard E. 1995: A Domino Theory of Regionalism, in: Baldwin, Richard E./Haaparanta, Pertti/ Kiander, Jaakko (eds): Expanding Membership of the European Union, Cambridge: Cambridge University Press.

Barnett, Michael N. 1995: Sovereignty, Nationalism, and Regional Order in the Arab States System, in: International Organization 49/3, 479-510.

Barnett, Michael N./Solingen, Etel 2007: Designed to Fail or Failure to Design? The Origins and Legacy of the Arab League, in: Acharya, Amitav and Johnston, Alastair lain (eds): Crafting Cooperation. Regional International Institutions in Comparative Perspective, Cambridge: Cambridge University Press, 180-220.

Beeson, Mark 2006: American Hegemony and Regionalism: The Rise of East Asia and the End of AsiaPacific, in: Geopolitics 11/4, 541-560.

Bhagwati, Jagdish 2008: Termites in the Trading System. How Preferential Agreements Undermine Free Trade, New York: Oxford University Press.

Börzel, Tanja A. 2005: Mind the Gap! European Integration between Level and Scope, in: Journal of European Public Policy 12/2, 1-20.

Börzel, Tanja A. (ed.) 2009: Coping with Accession to the European Union. New Modes of Environmental Governance, Houndmills: Palgrave Macmillan.

Börzel, Tanja A. 2010a: European Governance - Negotiation and Competition in the Shadow of Hierarchy, in: Journal of Common Market Studies 48/2, 191-219. 
Börzel, Tanja A. 2010b: The Transformative Power of Europe Reloaded: The Limits of External Europeanization, in: KFG Working Paper Series 11, February 2010.

Börzel, Tanja A. 2011: When Europe Hits ... Across its Borders. Europeanization and the Near Abroad, in: Comparative European Politics 9/4 (forthcoming).

Börzel, Tanja A./Risse, Thomas 2003: Conceptualising the Domestic Impact of Europe, in: Featherstone, Kevin/Radaelli, Claudio (eds): The Politics of Europeanisation, Oxford: Oxford University Press, 57-80.

Börzel, Tanja A./Risse, Thomas 2009: Diffusing (Inter-) Regionalism. The EU as a Model of Regional Integration, in: KFG Working Paper Series 7, September 2009.

Börzel, Tanja A./van Hüllen, Vera 2011: Good Governance and Bad Neighbours. The End of Transformative Power Europe?, in: KFG Working Paper Series (forthcoming).

Börzel, Tanja A./Goltermann, Lukas/Lohaus, Mathis/Striebinger, Kai (eds) 2012: Roads to Regionalism. Genesis, Design, and Effects of Regional Organizations, Aldershot: Ashgate.

Breslin, Shaun (ed.) 2002: New Regionalism in the Global Political Economy: Theories and Cases, London: Routledge.

Bruszt, Laszlo/McDermott, Gerald A. 2009: Transnational Integration Regimes as Development Programs, in: Bruszt, Laszlo/Holzhacker, Ronald (eds): The Transnationalization of Economies, States, and Civil Societies - New Modes of Governance in Europe, New York: Springer 23-60.

Bulmer, Simon/Lequesne, Christian (eds) 2005: Member States and the European Union, Oxford: Oxford University Press.

Burley, Anne-Marie/Mattli, Walter 1993: Europe before the Court: A Political Theory of Legal Integration, in: International Organization 47/1, 41-76.

Buzan, Barry/Weasver, Ole 2003: Regions and Powers: The Structure of International Security, Cambridge: Cambridge University Press.

Cameron, Maxwell A./Tomlin, Brian W. 2002: The Making of NAFTA: How the Deal Was Done, Cambridge: Cambridge University Press.

Caporaso, James A. 1996: The European Union and Forms of the State: Westphalia, Regulatory, or PostModern?, in: Journal of Common Market Studies 34/1, 29-52.

Checkel, Jeffrey T. 1999: Social Construction and Integration, in: Journal of European Public Policy 6/4, 545-560.

Checkel, Jeffrey T. (ed.) 2005: International Institutions and Socialization in Europe, in: International Organization 59/4.

Choi, Young Jong/Caporaso, James A. 2002: Comparative Regional Integration, in: Carlsnaes, Walter/Risse, Thomas/Simmons, Beth A. (eds): Handbook of International Relations, London: Sage.

Clarkson, Stephen 2008: Does North America Exist? Governing the Continent After NAFTA and 9/11, Toronto: University of Toronto Press.

Coleman, Katharina P. 2007: International Organization and Peace Enforcement: The Politics of International Legitimacy, Cambridge: Cambridge University Press.

Collins, Kathleen 2009: Economic and Security Regionalism among Patrimonial Authoritarian Regimes, in: Europe Asia Studies 61/2, 249-281.

Cooley, Alexander/Spruyt, Hendrik (eds) 2009: Contracting States. Sovereign Transfer in International Relations, Princeton, NJ: Princeton University Press.

Cooper, Robert 2003: The Breaking of Nations: Order and Chaos in the Twenty-First Century, London: Atlantic Books.

Cowles, Maria Green 1995: Setting the Agenda for a New Europe: The ERT and EC 1992, in: Journal of Common Market Studies 33/4, 611-628. 
Cowles, Maria Green/Caporaso, James A./Risse, Thomas (eds) 2001: Transforming Europe. Europeanization and Domestic Change, Ithaca: Cornell University Press.

De Lombaerde, Philippe/Schulz, Michael (eds) 2009: The EU and World Regionalism. The Makability of Regions in the 21st Century, Aldershot: Ashgate.

Dent, Christopher M. 2008: East Asia and Regionalism, London: Routledge.

Deutsch, Karl W./Burrell, Sidney A./Kann, Robert A. 1957: Political Community and the North Atlantic Area: International Organization in the Light of Historical Experience, Princeton: Princeton University Press.

Diez, Thomas 1999: Speaking ,Europe': The Politics of Integration Discourse, in: Journal of European Public Policy 6/4, 598-613.

Dolowitz, David P./Marsh, David 2000: Learning from Abroad: The Role of Policy Transfer in Contemporary Policy-Making, in: Governance 13/1, 5-24.

Edi, Eric M. 2007: Globalization and Politics in the ECOWAS Countries, Durham, NC: Carolina Academic Press.

Eising, Rainer/Kohler-Koch, Beate 1999: Introduction. Network Governance in the European Union, in Kohler-Koch, Beate/Eising, Rainer (eds): The Transformation of Governance in the European Union, London: Routledge, 3-13.

Epstein, Rachel A. 2008: In Pursuit of Liberalism: The Power and Limits of International Institutions in Postcommunist Europe, Baltimore: Johns Hopkins University Press.

Etzioni, Amitai 1965: Political Unification: A Comparative Study of Leaders and Forces, New York: Holt, Rinehart and Winston.

Falkner, Gerda/Treib, Oliver/Holzleitner, Elisabeth 2008: Compliance in the European Union. Living Rights or Dead Letters?, Aldershot: Ashgate.

Farrell, Mary 2009: EU Policy Towards Other Regions: Policy Learning in the External Promotion of Regional Integration, in: Journal of European Public Policy 16/8, 1165-1184.

Farrell, Mary 2007: From EU Model to External Policy? Promoting Regional Integration in the Rest of the World, in: Meunier, Sophie/McNamara, Kathleen R. (eds): Making History: European Integration and Institutional Change at Fifty, Oxford: Oxford University Press, 299-315.

Farrell, Mary/Hettne, Bjorn/van Langenhove, Luk (eds) 2005: Global Politics of Regionalism: Theory and Practice, London and Ann Arbor, MI: Pluto Press.

Fawcett, Louise/Gandois, Helene J. 2010: Regionalism in Africa and the Middle East: Implications for EU Studies, in: Journal of European Integration 32/ 6, 617-636.

Fawcett, Louise/Hurrell, Andrew (eds) 2000: Regionalism in World Politics. Regional Organizations and International Order, Oxford: Oxford University Press.

Fawcett, Louise/Serrano, Monica (eds) 2005: Regionalism and Governance in the Americas: Continental Drift, Houndmills: Palgrave Macmillan.

Fawn, Rick 2009: ,Regions' and Their Study: Wherefrom, What For and Whereto?, in: Review of International Studies 35/S1, 5-34.

Featherstone, Kevin/Radaelli, Claudio (eds) 2003: The Politics of Europeanisation, Oxford: Oxford University Press.

Finnemore, Martha 1993: International Organization as Teachers of Norms: The United Nations Educational, Scientific, and Cultural Organization and Science Policy, in: International Organization 47/4, 565597.

Finnemore, Martha/Sikkink, Kathryn 1998: International Norm Dynamics and Political Change, in: International Organization 52/4, 887-917.

Francis, David J. 2006: Uniting Africa: Building Regional Security Systems, Aldershot: Ashgate. 
Frieden, Jeffry 2002: Real Sources of European Currency Policy: Sectoral Interests and European Monetary Integration, in: International Organization 56/4, 831-860.

Gilpin, Robert 1987: The Political Economy of International Relations, Princeton: Princeton University Press.

Goetz, Klaus H. 2005: The New Member States and the EU: Responding to Europe, in: Bulmer, Simon/ Lequesne, Christian (eds) 2005: Member States of the European Union, Oxford: Oxford University Press, 254-280.

Goltermann, Lukas 2012: State Capacity and Compliance in ASEAN, in: Börzel, Tanja A./Goltermann, Lukas/ Lohaus, Mathis/Striebinger, Kai (eds): Roads to Regionalism. Genesis, Design, and Effects of Regional Organizations, Aldershot: Ashgate.

Gomez Mera, Laura 2005: Explaining MERCOSUR's Survival: Strategic Sources of Argentine-Brazilian Convergence, in: Journal for Latin American Studies 22/1, 85-98.

Gourevitch, Peter 1978: The Second Image Reversed: The International Sources of Domestic Politics, in: International Organization 32/4, 881-912.

Gowa, Joanne 1994: Allies, Adversaries, and International Trade, Princeton, NJ: Princeton University Press.

Graziano, Paolo/Vink, Maarten P. (eds) 2006: Europeanization: A Handbook for a New Research Agenda, Houndmills and London: Palgrave/Macmillan.

Gruber, Lloyd 2000: Ruling the World: Power Politics and the Rise of Supranational Institutions, Princeton, NJ: Princeton University Press.

Grugel, Jean B. 2004: New Regionalism and Modes of Governance. Comparing US and EU Strategies in Latin America, in: European Journal of International Relations 10/4, 602-626.

Haas, Ernst B. 1956: Regionalism, Functionalism and Universal Organization, in: World Politics 8/2, 238263.

Haas, Ernst B. 1958: The Uniting of Europe. Political, Social, and Economic Forces 1950-1957, Stanford: Stanford University Press.

Haas, Ernst B. 1961: International Integration: The European and the Universal Process, in: International Organization 15/3, 366-392.

Haas, Ernst B. 1964: Beyond the Nation-State. Functionalism and International Organization, Stanford: Stanford University Press.

Haas, Ernst B. 1967: The Uniting of Europe and the Uniting of Latin America, in: Journal of Common Market Studies 5/4, 315-343.

Haas, Ernst B. 1970: The Study of Regional Integration: Reflections on the Joy and Anguish of Pretheorizing, in: International Organization 24/4, 607-646.

Haas, Ernst B. 1975: The Obsolence of Regional Integration Theory, in: Research Series 25: Berkeley: Institute of International Studies, University of California,

Haas, Ernst B./Schmitter, Philippe C. 1964: Economics and Differential Patterns of Political Integration: Projections about Unity in Latin America, in: International Organization 18/4, 705-737.

Hancock, Kathleen J. 2009: Regional Integration. Choosing Plutocracy, Houndmills: Palgrave Macmillan.

Hemmer, Christopher/Katzenstein, Peter J. 2002: Why There is No NATO in Asia? Collective Identity, Regionalism, and the Origins of Multilateralism, in: International Organization 36/3, 575-607.

Henry, Laurence 2007: The ASEAN Way and Community Integration. Two Different Models of Regionalism, in: European Law Journal 13/6, 857-879.

Herbst, Jeffrey 2007: Crafting Regional Cooperation in Africa, in Acharya, Amitav/Johnston, Alastair Ian (eds): Crafting Cooperation. Regional International Institutions in Comparative Perspective, Cambridge: Cambridge University Press, 129-144.. 
Hettne, Bjorn 2005: Beyond the ,New'Regionalism, in: New Political Economy 10/4, 543-571.

Hettne, Bjorn/Inotai, András/Sunkel, Oswaldo 1999: Globalism and the New Regionalism, Basingstoke: Macmillan.

Hettne, Bjorn/Söderbaum, Fredrik 2000: Theorising the Rise of Regionness, in: New Political Economy 5/3, 457-474.

Hettne, Bjorn/Söderbaum, Fredrik 2008: The Future of Regionalism, in: Cooper, Andrew F./Hughes, Christopher W./De Lombaerde, Philippe (eds): Regionalisation and Global Governance: The Taming of Globalization, London: Routledge,61-79.

Hiscox, Michael J. 2006: Through a Glass and Darkly: Framing Effects and Individuals' Attitudes towards International Trade, in: International Organization 60/3, 755-780.

Hix, Simon 1994: The Study of the European Community: The Challenge to Comparative Politics, in: West European Politics 17/1, 1-30.

Hoffmann, Stanley 1966: Obstinate or Obsolete? The Fate of the Nation-State and the Case of Western Europe, in: Daedalus 95/3, 865-921.

Holt, Victoria/Shanahan, Moira 2005: African Capacity-Building for Peace Operations: UN Collaboration with the African Union and ECOWAS, in: Report of the Henry L. Stimson Center, Washington DC.

Hooghe, Liesbet/Marks, Gary 2001: Multi-Level Governance and European Integration, Lanham: Rowman \& Littlefield.

Hooghe, Liesbet/Marks, Gary 2009: A Postfunctionalist Theory of European Integration: From Permissive Consensus to Constraining Dissensus, in: British Journal of Political Science 39/1, 1-23.

Hummel, Felix/Lohaus, Mathis 2012: MERCOSUR: Integration through Presidents and Paymasters, in: Börzel, Tanja A./Goltermann, Lukas/Lohaus, Mathis/Striebinger, Kai (eds): Roads to Regionalism. Genesis, Design, and Effects of Regional Organizations, Aldershot: Ashgate.

Hurrell, Andrew 1995: Explaining the Resurgence of Regionalism in World Politics, in: Review of International Studies 21/4, 545-566.

Jetschke, Anja 2010: Is Regional Integration Contagious? European Integration and Regional Organization in Asia, in: KFG Working Paper Series 17, October 2010.

Jones, David M./Smith, Michael L. R. 2007: Making Process, Not Progress: ASEAN and the Evolving East Asian Regional Order, in: International Security 32/1, 148-184.

Kanthak, Leon 2012: Explaining Differences in the Institutional Design of ASEAN and NAFTA, in: Börzel, Tanja A./Goltermann, Lukas/Lohaus, Mathis/Striebinger, Kai (eds): Roads to Regionalism. Genesis, Design, and Effects of Regional Organizations, Aldershot: Ashgate

Katsumata, Hiro 2009: ASEAN and Human Rights: Resisting Western Pressure or Emulating the West?, in: The Pacific Review 22/5, 619-637.

Katzenstein, Peter J. 2005: A World of Regions. Asia and Europe in the American Imperium, Ithaca, NY: Cornell University Press.

Kelley, Judith 2004a: International Actors on the Domestic Scene: Membership Conditionality and Socialization by International Institutions, in: International Organization 58/3, 425-457.

Kelley, Judith 2004b: Ethnic Politics in Europe. The Power of Norms and Incentives, Princeton: Princeton University Press.

Keohane, Robert O./Hoffmann, Stanley 1991: Institutional Change in Europe in the 1980s, in: Keohane, Robert 0./Hoffmann, Stanley (eds): The New European Community: Decisionmaking and Institutional Change, Oxford; Boulder: Westview Press.

Khadduri, Majid 1946: Towards an Arab Union: The League of Arab States, in: American Political Science Review 40/1, 90-100.

Kirschner, Veronika/Stapel, Sören 2012: Does Regime Type Matter? Regional Integration from the Nation States' Perspectives in ECOWAS, in: Börzel, Tanja A./Goltermann, Lukas/Lohaus, Mathis/ 
Striebinger, Kai (eds): Roads to Regionalism. Genesis, Design, and Effects of Regional Organizations, Aldershot: Ashgate.

Kohler-Koch, Beate 1996: The Strength of Weakness. The Transformation of Governance in the EU, in: Gustavsson, Sverker/Lewin, Leif (eds): The Future of the Nation State. Essays on Cultural Pluralism and Political Integration, Stockholm: Nerenius \& Santerus, 93-117.

Kohler-Koch, Beate/Eising, Rainer (eds) 1999: The Transformation of Governance in Europe, London: Routledge.

Kohler-Koch, Beate/Rittberger, Berthold 2006: The ,Governance Turn' in EU Studies, in: Journal of Common Market Studies 44/1, 27-49.

Koitsch, Constanze 2012: Institutional Similarities Between Regional Organizations - An Analysis of ECOWAS and the Arab League, in: Börzel, Tanja A./Goltermann, Lukas/Lohaus, Mathis/Striebinger, Kai (eds): Roads to Regionalism. Genesis, Design, and Effects of Regional Organizations, Aldershot: Ashgate.

Koremenos, Barbara/Lipson, Charles/Snidal, Duncan 2001: The Rational Design of International Institutions, in: International Organization 55/4, 761-799.

Koremenos, Barbara/Lipson, Charles/Snidal, Duncan (eds) 2004: The Rational Design of International Institutions, Cambridge: Cambridge University Press.

Korte, Annika 2012: Why Did NAFTA and ASEAN Set Up Dispute Settlement Procedures?, in: Börzel, Tanja A./Goltermann, Lukas/Lohaus, Mathis/Striebinger, Kai (eds): Roads to Regionalism. Genesis, Design, and Effects of Regional Organizations, Aldershot: Ashgate.

Krome, Corinna 2012: ASEAN and Civil Society - An Incompatible Relationship?, in: Börzel, Tanja A./ Goltermann, Lukas/Lohaus, Mathis/Striebinger, Kai (eds): Roads to Regionalism. Genesis, Design, and Effects of Regional Organizations, Aldershot: Ashgate.

Kubicek, Paul 1997: Regionalism, Nationalism, and Realpolitik in Central Asia, in: Europe Asia Studies 49/4, 637-655.

Lavenex, Sandra 2008: A Governance Perspective on the European Neighbourhood Policy. Integration Beyond Conditionality?, in: Journal of European Public Policy 15/6, 938-955.

Lavenex, Sandra/Lehmkuhl, Dirk/Wichmann, Nicole 2007: Die Externe Governance der Europäischen Union: neue Steuerungsmodi und differenzierte Integration mit assoziierten Nachbarstaaten, in: Politische Vierteljahresschrift, Sonderheft „Die Europäische Union. Governance und PolicyMaking" 40, 367-388.

Levi-Faur, David 2005: The Global Diffusion of Regulatory Capitalism, in: Annals of the American Academy of Political and Social Science 598, 12-32.

Lindberg, Leon N. 1963: The Political Dynamics of European Economic Integration, Stanford: Stanford University Press.

Lindberg, Leon N. 1970: Political Integration as a Multidimensional Phenomenon Requiring Multivariate Measurement, in: International Organization 24/4, 649-731.

Lindberg, Leon N./Scheingold, Stuart A. 1970: Europe's Would-Be Polity, Englewood Cliffs: Prentice-Hall.

Lindberg, Leon N./Scheingold, Stuart A. (eds) 1971: Regional Integration. Theory and Research, Cambridge: Harvard University Press.

Lorca-Susino, Maria 2010: The Euro in the 21st Century. Economic Crisis and Financial Uproar, Aldershopt: Ashgate.

Malamud, Andrés 2010: Latin American Regionalism and EU Studies, in: Journal of European Integration 32/6, 637-657.

Manners, Ian 2002: Normative Power Europe. A Contradiction in Terms?, in: Journal of Common Market Studies 40/2, 235-258.

Mansfield, Edward D. 1998: The Proliferation of Preferential Trading Arrangements, in: Journal of Conflict Resolution 42/5, 523-543. 
Mansfield, Edward D./Milner, Helen V. 1997: The Political Economy of Regionalism, New York: Columbia University Press.

Mansfield, Edward D./Milner, Helen V. 1999: The New Wave of Regionalism, in: International Organization 53/3, 589-627.

Mansfield, Edward D./Milner, Helen V./Rosendroff, B. Peter 2000: Free to Trade: Democracies, Autocracies, and International Trade, in: American Political Science Review 94/2, 305-321.

Mansfield, Edward D./Pevehouse, Jon C. 2006: Democratization and International Organizations, in: International Organization 60/1, 137-167.

Mansfield, Edward D./Reinhardt, Eric 2003: Multilateral Determinants of Regionalism: The Effects of GATT/ WTO on the Formation of Preferential Trading Arrangements, in: International Organization 57/4, 829-862.

Marks, Gary 1993: Structural Policy and Multilevel Governance in the European Community, in Cafruny, Alan W./Rosenthal, Glenda G. (eds): The State of the European Community II: Maastricht Debates and Beyond, Boulder: Lynne Riener.

Marks, Gary/Hooghe, Liesbet/Blank, Kermit 1996: European Integration from the 1980s: State-centric v. Multi-level Governance, in: Journal of Common Market Studies 34/3, 341-378.

Mattli, Walter 1999a: Explaining Regional Integration Outcomes, in: Journal of European Public Policy 6/1, 1-27.

Mattli, Walter 1999b: The Logic of Regional Integration, Cambridge: Cambridge University Press.

Means, Gordon P. 1995: ASEAN Policy Responses to North American and European Trading Arrangements, in: Acharya, Amitav/Stubbs, Richard (eds): New Challenges for ASEAN: Emerging Policy Issues, Vancouver: UBC Press.

Meyer, John W./Kamens, David H./Benavot, Aaron/Cha, Yua-Kyung/Wong, Suk-Ying 1992: School Knowledge for the Masses: World Models and National Primary Curricular Categories, Bristol, PA: Falmer Press.

Meyer, John W./Rowan, Brian 1977: Institutionalized Organizations: Formal Structures as Myth and Ceremony, in: American Journal of Sociology 83/2, 340-363.

Milner, Helen V. 1988: Resisting Protectionism: Global Industries and the Politics of International Trade, Princeton: Princeton University Press.

Milner, Helen V. 1992: International Theories of Cooperation among Nations: Strenghts and Weaknesses, in: World Politics 44/3, 466-496.

Milner, Helen V. 1995: Regional Economic Co-operation, Global Markets and Domestic Politics: A Comparison of NAFTA and the Maastricht Treaty, in: Journal of European Public Policy 2/3, 337-360.

Milner, Helen V. 1997: Interests, Institutions and Information. Domestic Politics and International Relations., Princeton, NJ: Princeton University Press.

Milward, Alan S. 1992: The European Rescue of the Nation-State, Berkeley: University of California Press.

Mitrany, David 1943: A Working Peace System. An Argument for the Functional Development of International Organization, London: Royal Institute of International Affairs.

Mitrany, David 1966: A Working Peace System, Chicago: Quadrangle Books.

Morales, Isidro 2002: The Governance of Global Issues through Regionalism: NAFTA as an Interface between Multilateral and North-South Policies, in: Journal of Social Science 55/1, 27-55.

Moravcsik, Andrew 1994: Why the European Community Strengthens the State: Domestic Politics and International Cooperation 52, Cambridge: Harvard University.

Moravcsik, Andrew 1997: Taking Preferences Seriously: A Liberal Theory of International Politics, in: International Organization 51/4, 513-553.

Moravcsik, Andrew 1998: The Choice for Europe: Social Purpose and State Power From Rome to Maastricht, Ithaca: Cornell University Press. 
Moravcsik, Andrew/Vachudova, Milada A. 2003: National Interests, State Power, and EU Enlargement, in: East European Politics and Societies 17/1, 42-57.

Musila, Jacob 2005: The Intensity of Trade Creation and Trade Diversion in COMESA, ECCAS and ECOWAS: A Comparative Analysis, in: Journal of African Economies 14/1, 117-141.

Nesadurai, Helen E. S. 2008: The Association of Southeast Asian Nations (ASEAN), in: New Political Economy $13 / 2,225-239$.

Nesadurai, Helen E. S. 2009: ASEAN and Regional Governance after the Cold War: From Regional Order to Regional Community, in: The Pacific Review 22/1, 91-118.

Nye, Joseph S. 1965: Patterns and Catalysts in Regional Integration, in: International Organization 19/4, 870-884.

Nye, Joseph S. 1968: Comparative Regional Integration: Concept and Measurement, in: International Organization 22/4, 855-880.

Nye, Joseph S. 1970: Comparing Common Markets: A Revised Neo-Functionalist Model, in: International Organization 24/4, 796-835.

Nye, Joseph S. 1971: Peace in Parts: Integration and Conflict in Regional Organizations, Boston: Little, Brown.

Oelsner, Andrea 2004: Consensus and Governance in Mercosur. Evolution of the South American Security Agenda, in: Security Agenda 40/191, 191-21.

Okolo, Julius Emeka 1985: Integrative and Cooperative Regionalism: The Economic Community of West African States, in: International Organization 39/1, 121-153.

Pevehouse, Jon C. 2005: Democracy from Above: Regional Organizations and Democratization, Cambridge: Cambridge University Press.

Pierson, Paul 1996: The Path to European Integration: A Historical Institutionalist Analysis, in: Comparative Political Studies 29/2, 123-163.

Pirzer, Christian 2012: MERCOSUR's Contribution to Democratic Consolidation, in: Börzel, Tanja A./ Goltermann, Lukas/Lohaus, Mathis/Striebinger, Kai (eds): Roads to Regionalism. Genesis, Design, and Effects of Regional Organizations, Aldershot: Ashgate.

Pollack, MarkA. 1997: Delegation, Agency, and Agenda Setting in the European Community, in: International Organization 51/1, 99-134.

Porrata-Doria Jr/Rafael A. 2005: Mercosur: The Common Market of the Southern Cone, Durham, NC: Carolina Academic Press.

Preusse, Heinz G. 2004: The New American Regionalism, Cheltenham: Edward Elgar.

Puchala, Donald J. 1972: Of Blind Men, Elephants and International Integration, in: Journal of Common Market Studies 10/3, 267-284.

Rhodes, Rod A. W. 1996: The New Governance: Governing without Government, in: Political Studies 44/4, 652-667.

Ribeiro Hoffmann, Andrea/van der Vleuten, Anna (eds) 2007: Closing or Widening the Gap? Legitimacy and Democracy in Regional Integration Organizations, Aldershot: Ashgate.

Risse, Thomas 2003: Social Constructivism and European Integration, in; Diez, Thomas/Wiener, Antje (eds): European Integration Theory, Oxford: Oxford University Press.

Risse, Thomas 2010: A Community of Europeans? Transnational Identities and Public Spheres, Itahaca, NY: Cornell University Press.

Risse, Thomas/Ropp, Stephen C./Sikkink, Kathryn (eds) 1999: The Power of Human Rights. International Norms and Domestic Change, Cambridge: Cambridge University Press.

Rogowski, Ronald 1989: Commerce and Coalitions: How Trade Affects Domestic Political Alignments, Princeton: Princeton University Press. 
Ruggie, John G. 1993: Territoriality and Beyond: Problematizing Modernity in International Relations, in: International Organization 47/1, 139-174.

Russett, Bruce 1967: International Regions and the International System. A Study in Political Ecology, Chicago: Rand-MacNally.

Sandholtz, Wayne/Zysman, John 1989: 1992: Recasting the European Bargain, in: World Politics 42/1, 95128.

Sbragia, Alberta 2008: Comparative Regionalism: What Might It Be?, in: Journal of Common Market Studies 46, 29-49.

Scharpf, Fritz W. 1996: Negative and Positive Integration in the Political Economy of European Welfare States, in Marks, Gary/Scharpf, Fritz W./Schmitter, Philippe C./Streeck, Wolfgang (eds): Governance in the European Union, London; Thousand Oaks; New Delhi: Sage.

Scharpf, Fritz W. 2001: Notes Toward a Theory of Multilevel Governing in Europe, in: Scandinavian Political Studies 24/1, 1-26.

Schimmelfennig, Frank 2007: Europeanization beyond Europe, in: Living Reviews in European Governance $1 / 1$.

Schimmelfennig, Frank/Scholtz, Hanno 2009: EU Democracy Promotion in the European Neighbourhood. Political Conditionality, Economic Development and Transitional Exchange, in: European Union Politics 9/2, 187-215.

Schimmelfennig, Frank/Sedelmeier, Ulrich 2005: The Europeanization of Central and Eastern Europe, Ithaca, NY: Cornell University Press.

Schimmelfennig, Frank/Sedelmeier, Ulrich 2006: Candidate Countries and Conditionality, in: Graziano, Paolo/Vink, Maarten P. (eds): Europeanization. New Research Agendas, Houndsmill: Palgrave Macmillan, 88-101.

Schirm, Stefan A. 2002: Globalization and the New Regionalism. Global Markets, Domestic Politics and Regional Co-operation, Cambridge: Polity Press.

Schmitter, Philippe C. 1991: The European Community as an Emergent and Novel Form of Political Domination, in: Working Paper 26, Madrid: Juan March Institute.

Schulz, Michael/Söderbaum, Fredrik/Öjendal, Joakim 2001: Introduction. A Framework for Understanding Regionalization, in: Schulz, Michael/Söderbaum, Fredrik/Öjendal, Joakim (eds): Regionalization in a Globalizing World. A Comparative Perspective on Forms, Actors and Processes, London and New York: ZED BOOKS.

Sedelmeier, Ulrich 2006: Europeanisation in New Member and Candidate States', in: Living Reviews of European Government 1/3, 4-34.

Söderbaum, Fredrik 2004: The Political Economy of Regionalism. The Case of Southern Africa, Basingstoke: Palgrave MacMillan.

Söderbaum, Fredrik/van Langenhove, Luk (eds) 2006: The EU as a Global Player: The Politics of Interregionalism, London: Routledge.

Söderbaum, Fredrik/Shaw, Timothy M. 2003: Theories of New Regionalism: A Palgrave Reader, Houndmills: Palgrave Macmillan.

Solingen, Etel 1998: Regional Order at Century's Dawn. Global and Domestic Influences and Grand Strategy, Princeton, NJ: Princeton University Press.

Spielau, Alexander 2012: Monetary Integration Through the Backdoor: Does NAFTA Promote Monetary Policy Harmonization in North America?, in: Börzel, Tanja A./Goltermann, Lukas/Lohaus, Mathis/ Striebinger, Kai (eds): Roads to Regionalism. Genesis, Design, and Effects of Regional Organizations, Aldershot: Ashgate.

Spinelli, Altiero/Rossi, Ernesto 2006 (1941): For a Free and United Europe. A Draft Manifesto. Reprint, in: Eilstrup-Sangiovanni, Mette (ed.): Debates on European Integration, Houndsmill: Palgrave.

Stein, Arthur A. 1983: Coordination and Collaboration: Regimes in an Anarchic World, in: Krasner, Stephen D. (ed.) 1983: International Regimes, Ithaca: Cornell University Press. 
Stone Sweet, Alec 2000: Governing with Judges: Constitutional Politics in Europe, Oxford: Oxford University Press.

Stone Sweet, Alec/Caporaso, James A. 1998: From Free Trade to Supranational Polity: The European Court and Integration, in: Stone Sweet, Alec/Sandholtz, Wayne (eds): European Integration and Supranational Governance, Oxford: Oxford University Press, 92-133.

Stone Sweet, Alec/Sandholtz, Wayne (eds) 1998a: European Integration and Supranational Governance, Oxford: Oxford University Press.

Stone Sweet, Alec/Sandholtz, Wayne 1998b: Integration, Supranational Governance, and the Institutionalization of the European Polity, in: Stone Sweet, Alec/Sandholtz, Wayne (eds): European Integration and Supranational Governance, Oxford: Oxford University Press.

Striebinger, Kai 2012: When Pigs Fly: ECOWAS and the Protection of Constitutional Order in Events of Coups d'Etat, in: Börzel, Tanja A./Goltermann, Lukas/Lohaus, Mathis/Striebinger, Kai (eds): Roads to Regionalism. Genesis, Design, and Effects of Regional Organizations, Aldershot: Ashgate.

Telò, Mario (ed.) 2001: European Union and New Regionalism: Regional Actors and Global Governance in a Post-Hegemonic Era, Aldershot: Ashgate.

Telò, Mario 2006: Europe: A Civilian Power? European Union, Global Governance, World Order, Houndsmill, Basingstoke: Palgrave, Macmillan.

Tussie, Diana 2009: Latin America: Contrasting Motivations for Regional Projects, in: Review of International Studies 35/S1, 169-188.

Union of International Associations 2000: Yearbook of International Organizations: Guide to Global Civil Society Networks, Munich: Saur.

Van Hüllen, Vera 2012: Europeanization through Cooperation? EU Democracy Promotion in Morocco and Tunisia, in: West European Politics 35/1 (forthcoming).

Wallace, Helen/Wallace, William (eds) 1996: Policy-Making in the European Union, Oxford: Oxford University Press.

Warleigh-Lack, Alex 2006: Towards a Conceptual Framework for Regionalisation: Bridging 'New Regionalism' and 'Integration Theory', in: Review of International Political Economy 13/5, 750-771.

Weintraub, Sidney (ed.) 2004: NAFTA's Impact on North America, Washington, D.C.: Center for Strategic and International Studies.

Whitman, Richard G. 1998: From Civilian Power to Superpower? The International Identity of the European Union, London: Macmillan.

Wilcox, Francis O. 1965: Regionalism and the United Nations, in: International Organization 19/3, 789811.

Winters, L. Alan/Venables, Anthony (eds) 1991: European Integration: Trade and Industry, Cambridge: Cambridge University Press.

Wirminghaus, Niklas 2012: Ephemeral Regionalism: The Proliferation of (Failed) Regional Integration Initiatives in Post-Soviet Eurasia, in: Börzel, Tanja A./Goltermann, Lukas/Lohaus, Mathis/ Striebinger, Kai (eds): Roads to Regionalism. Genesis, Design, and Effects of Regional Organizations, Aldershot: Ashgate.

Yarbrough, Beth V./Yarbrough, Robert M. 1992: Cooperation and Governance in International Trade: The Strategic Organizational Approach, Princeton, NJ: Princeton University Press. 
The Kolleg-Forschergruppe - Encouraging Academic Exchange and Intensive Research

The Kolleg-Forschergruppe (KFG) is a new funding programme launched by the German Research Foundation in 2008. It is a centrepiece of the KFG to provide a scientifically stimulating environment in which innovative research topics can be dealt with by discourse and debate within a small group of senior and junior researchers.

The Kolleg-Forschergruppe "The Transformative Power of Europe" brings together research on European affairs in the Berlin-Brandenburg region and institutionalizes the cooperation with other universities and research institutions. It examines the role of the EU as promoter and recipient of ideas, analyzing the mechanisms and effects of internal and external diffusion processes in three research areas:

- Identity and the Public Sphere

- Compliance, Conditionality and Beyond

- Comparative Regionalism and Europe's External Relations

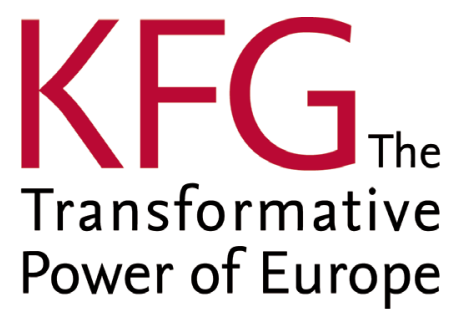

